\title{
Shear wave tomography of China using joint inversion of body and surface wave constraints
}

\author{
Mathias Obrebski, ${ }^{1,2}$ Richard M. Allen, ${ }^{1}$ Fengxue Zhang, ${ }^{3}$ Jiatie Pan, ${ }^{3}$ Qingju Wu, ${ }^{3}$ \\ and Shu-Huei Hung ${ }^{4}$ \\ Received 7 March 2011; revised 16 November 2011; accepted 17 November 2011; published 26 January 2012.
}

[1] The India-Eurasia collision and the decratonization of the North China Craton have drawn much attention from the scientific community. Here we provide the first large-scale $\mathrm{S}$ wave velocity model for China (CH11-S) based on constraints from both teleseismic surface and body waves. We take advantage of the recent deployment of the 140 permanent stations of the Chinese Digital Seismic Network and temporary network deployments to resolve both the lithospheric and deeper mantle structure. Slow velocities are widespread in the crust and upper mantle. Deeply rooted fast anomalies are located beneath the stable Yangtze Craton and the western (Ordos) block of the North China Craton. An upper mantle fast anomaly is observed beneath the eastern block of the North China Craton and could represent thermally eroded or delaminated Precambrian lithosphere. Another flat and fast feature appears beneath the Tibetan Plateau from 50 to $250 \mathrm{~km}$ depth. This may represent the Indian slab stalled in the mantle due to its buoyancy or a lithospheric instability triggered by the India-Eurasia collision. A large fast anomaly apparently stagnant in the transition zone is observed beneath the Yangtze Craton and may play a role in the stability of this block. In contrast, on both sides of the South China Block, active and reactivated areas coincide with oceanic slab material that has already sunk into the lower mantle and that may have enhanced tectonic activity by forcing convection. Finally, the upper mantle beneath Tibet seems almost completely surrounded by adjacent high-velocity and presumably strong blocks.

Citation: Obrebski, M., R. M. Allen, F. Zhang, J. Pan, Q. Wu, and S.-H. Hung (2012), Shear wave tomography of China using joint inversion of body and surface wave constraints, J. Geophys. Res., 117, B01311, doi:10.1029/2011JB008349.

\section{Introduction}

[2] China is a wide area that encompasses three major partially stable blocks (Tarim Basin, North China Craton, South China Block) connected by deformation belts, as well as active areas mainly along the Pacific-Philippine subduction realm and the India-Eurasia collision realm (Figure 1). The large scale tectonic processes including uplift, contraction and crust thickening, which are currently deforming the Tibetan Plateau and surrounding areas, as well as the reactivation of the eastern side of the North China Craton evidenced by significant seismicity, volcanism and extension, have raised particular interest for several decades.

[3] The deployments of permanent stations and temporary experiments have multiplied in China over the last 25 years

\footnotetext{
${ }^{1}$ Seismological Laboratory, University of California, Berkeley, California, USA.

${ }^{2}$ Now at Laboratoire d'Océanographie Spatiale, Centre Ifremer de Brest, Service DYNECO/PHYSED, Plouzané, France.

${ }^{3}$ Institute of Geophysics, Chinese Earthquake Administration, Beijing, China.

${ }^{4}$ Department of Geosciences, National Taiwan University, Taipei, Taiwan.

Copyright 2012 by the American Geophysical Union. 0148-0227/12/2011JB008349
}

and have generated tomographic models based on surface waves from earthquakes [Lebedev and Nolet, 2003; Huang et al., 2003, 2009] and seismic noise correlations [Zheng et al., 2008; Sun et al., 2010], local and regional S waves [Sun et al., 2008], and teleseismic P waves [Huang and Zhao, 2006; Li and van der Hilst, 2010]. Surface and body wave tomography have highlighted, respectively, the structure of the lithosphere and asthenosphere. On a large scale, fast velocities were found to be confined to the stable Ordos and Yangtze blocks and along the India-Eurasia collision realm, while slow velocities are widespread elsewhere, including the eastern part of the North China Craton. Local models show the detailed structure of the subducting Indian Plate [Li et al., 2008] and possible delamination beneath the North China Basin [Xu and Zhao, 2009]. Large aperture regional models based on teleseismic arrivals also illuminate the deep P wave velocity structure of the mantle [Huang and Zhao, 2006; Li and van der Hilst, 2010], showing the presence of flat fast features connected to the currently subducting Philippine and Pacific slabs which have been hinted previously in a global $\mathrm{P}$ wave model [Bijwaard et al., 1998].

[4] Here we focus on the $\mathrm{S}$ wave velocity structure of the crust and mantle down to $900 \mathrm{~km}$ beneath China. We take advantage of the recent expansion of the Chinese Digital 


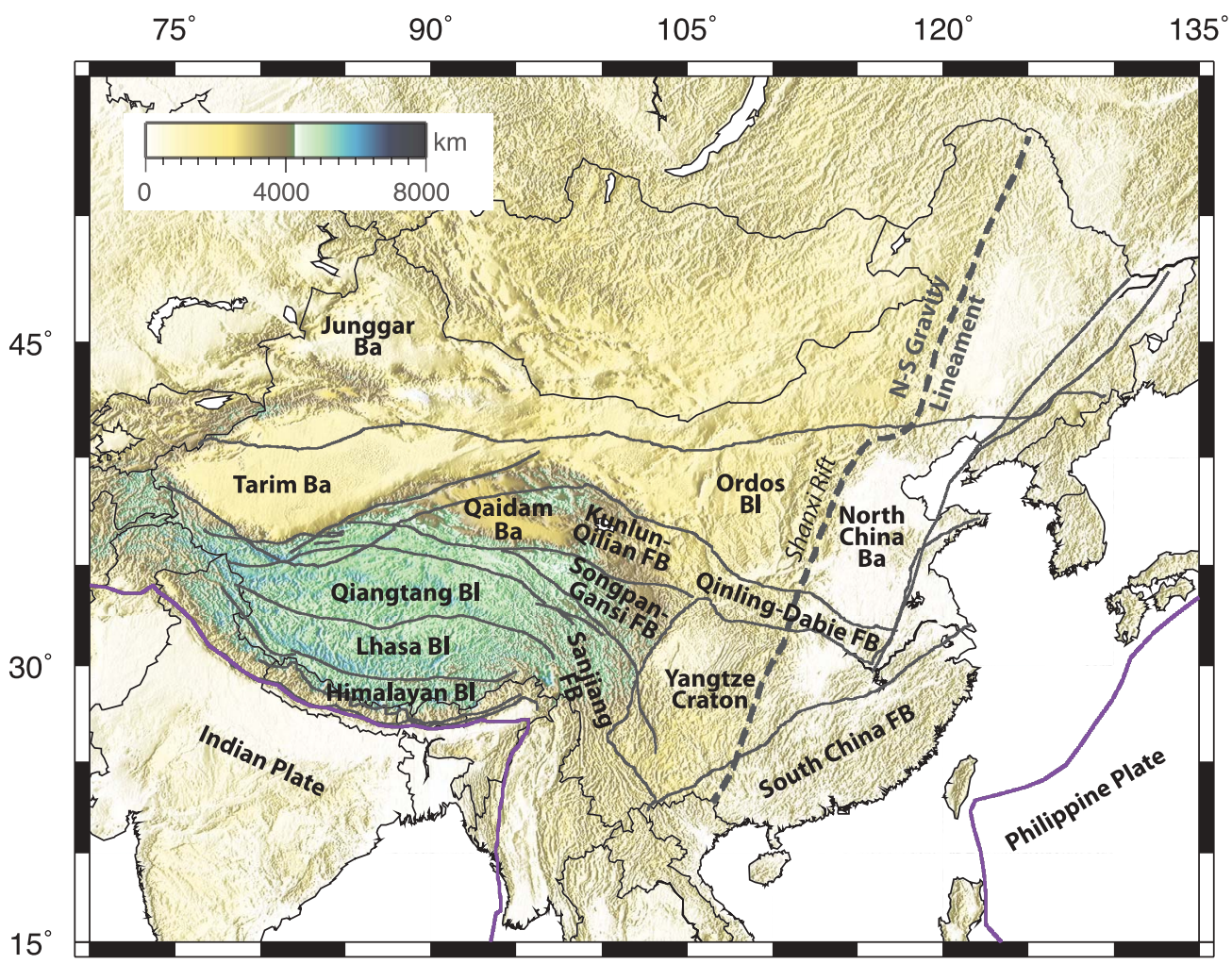

Figure 1. Geologic-tectonic features of China overlaid on topography. The continuous gray lines mark the major faults and boundaries between tectonic provinces. The thick gray dashed line depicts the N-S Gravity Lineament [Ma, 1987]. The purple lines are plate boundaries. Ba, Bl and FB stand for "basin," "block" and "fold belt." The Ordos Block, the Shanxi Rift and the North China Basin form the North China Craton. The Yangtze Craton together with the South China Fold Belt form the South China Block.

Seismic Network (CDSN) to 140 permanent stations, along with the data sets from several temporary deployments. Following previous studies, [Masters et al., 1996; Mégnin and Romanowicz, 2000; West et al., 2004], we use a joint inversion scheme that integrates teleseismic $\mathrm{S}$ wave traveltimes and Rayleigh surface wave dispersion curves [Obrebski et al., 2011] and that allows us to close the gap between well resolved lithospheric and mantle structures, as provided respectively by regional surface wave and body wave tomography.

\section{Geotectonic Setting}

[5] The Chinese lithosphere exhibits three main blocks (Figure 1): the Tarim Basin, the South China Block and the North China Craton. Their amalgamation was completed by Permo-Triassic time [Metcalfe, 2006]. The Archean North China Craton is composed of the western (Ordos) block and eastern (today's North China Basin) block that collided either at $2.5 \mathrm{Ga}$ or at $1.85 \mathrm{Ga}$ (see review of Kusky et al. [2007]) along the region now occupied by the Shanxi Rift. The North China Craton has remained internally stable from middle Proterozoic to late Paleozoic. Amalgamation of the Proterozoic Yangtze Craton and South China Fold Belt to form the South China Block first occurred during the 1.0-0.85 Ga Jinning Orogeny. The closure of the eastern Paleo-Tethys Ocean during the Late Triassic-Early Jurassic
Indosinian orogeny led to the collision of the North China Craton and the South China Block along the Qiling-Dabie Fold Belt [Ren et al., 1987]. To the southwest, the Qiangtang and Lhasa blocks that form a large part of today's Tibetan Plateau (Figure 1) collided and sutured to Eurasia between Late Jurassic and Early Cretaceous [Metcalfe, 2006]. The collision between the Indian Plate and Eurasia initiated at the end of the Cretaceous. This event completed the formation of southwestern China and led to the extrusion of Southeastern Asian terranes [Tapponnier et al., 1982].

[6] Tectonic deformation and the establishment of a broad magmatic zone across eastern China took place during the Late Jurassic-Early Cretaceous Yanshanian orogeny. This event is thought to be the consequence of the combined effects of continuous collision between the North China Craton and South China Block, the closure of the Paleo-Asia Ocean between the North China Craton and the Siberia Craton, and the subduction of the Pacific Sea Plate. The tectonics of much of Asia then became extensional at 130 $120 \mathrm{Ma}$, possibly due to post-orogenic gravitational collapse [Meng, 2003], the dynamics of the Pacific Slab [Ma et al., 1984; Liu, 1987; Tian et al., 1992] and later India-Eurasia collision [Ren et al., 2002; Liu et al., 2004]. In eastern China, the development of major rift zones, such as the Shanxi Rift, and large basins occurred from Jurassic to Cretaceous and then from Cretaceous to present [Griffin et al., 1998; Ren et al., 2002]. 


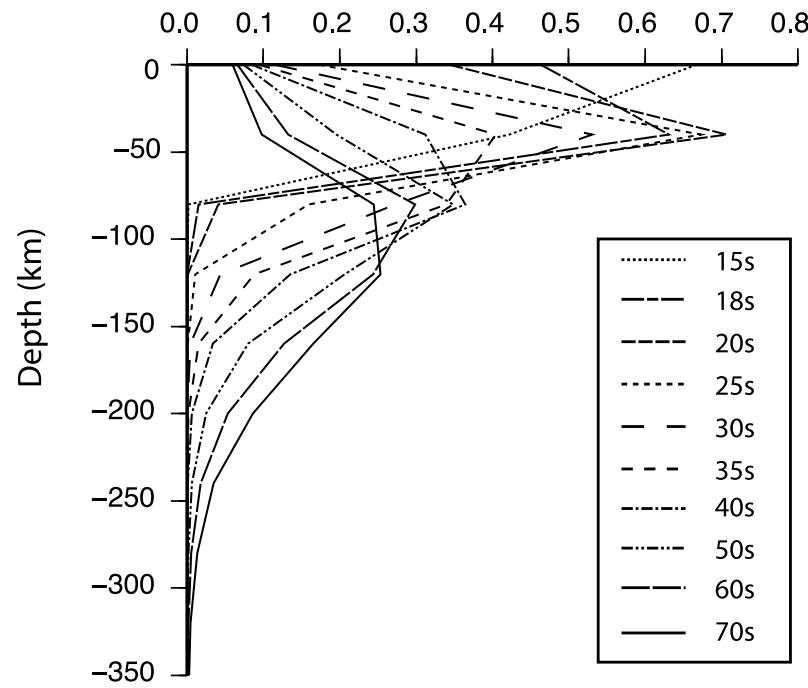

Figure 2. Vertical surface wave sensitivity kernels as a function of depth and period. The curves represent the response of the phase velocity to a unit change in the shear velocity in the depth interval $(40 \mathrm{~km})$.

[7] The geophysical setting of China is marked by a major E-W contrast along the North-South Gravity Lineament (Figure 1), with lower Bouguer anomaly, thicker lithosphere (as indicated by the Low Velocity Zone) and lower heat flow to the west $[M a, 1987]$. Locally, the North-South Gravity Lineament coincides with the Shanxi Rift and the internal boundary of the North China Craton. The eastern block of the North China Craton lost 80-140 km of Archean lithospheric root since the Ordovician [Griffin et al., 1998] and seems to be reactivated as indicated by internal extension, volcanism and seismicity [Kusky et al., 2007; Menzies et al., 2007; An et al., 2009].

\section{Data}

[8] The backbone of the array of seismic stations used in this study is the Chinese Digital Seismic Network. We used ten years of recording, from January 2001 to June 2010. The number of CDSN stations increased from $~ 30$ in 2001 to more than 140 since 2009 . We also used the data from several temporary deployments available at the IRIS DMC: Namche Barwa Tibet (XE, 2003/07/17- 2004/10/24), Tian Shan Continental Dynamics (XW, 1997/09/28-2000/08/11), Nepal-Himalaya-Tibet Seismic Transect (XF, 2002/09/12, 2005/08/29), NE China Seismic Experiment (XI, 1998/06/ 27-1999/03/24), INDEPTH III (XR, 1997/07/11-1999/06/ 07) and 2003MIT-China (YA, 2003/09/20-2004/09/15).

\subsection{Surface Wave Data Set}

[9] The surface waves are intended to provide constraints on the upper part of our tomographic model. We use Rayleigh waves, which are polarized in the radial plane (ie, the plane that contains the seismic source, the center of the earth and the seismic station). Figure 2 illustrates the vertical sensitivity kernel of the ten periods used in this study $(15,18,20,25,30,35,40,50,60$ and $70 \mathrm{~s})$. The sensitivity of the longest period $(70 \mathrm{~s})$ peaks around $110 \mathrm{~km}$, but has sensitivity to $\sim 200 \mathrm{~km}$. We initially selected all available events with magnitude ranging from 5.5 to 7 , epicentral distance between $15^{\circ}$ and $100^{\circ}$, and source shallower than $70 \mathrm{~km}$ depth. To enhance the number of raypaths, we also used data from permanent stations around China. The final data set is made of 10,720 raypaths from $\sim 825$ events (Figure 3a) recorded at $\sim 500$ stations. Figure 4 shows the raypath coverage achieved at $15,30,50$ and $70 \mathrm{~s}$. Ray
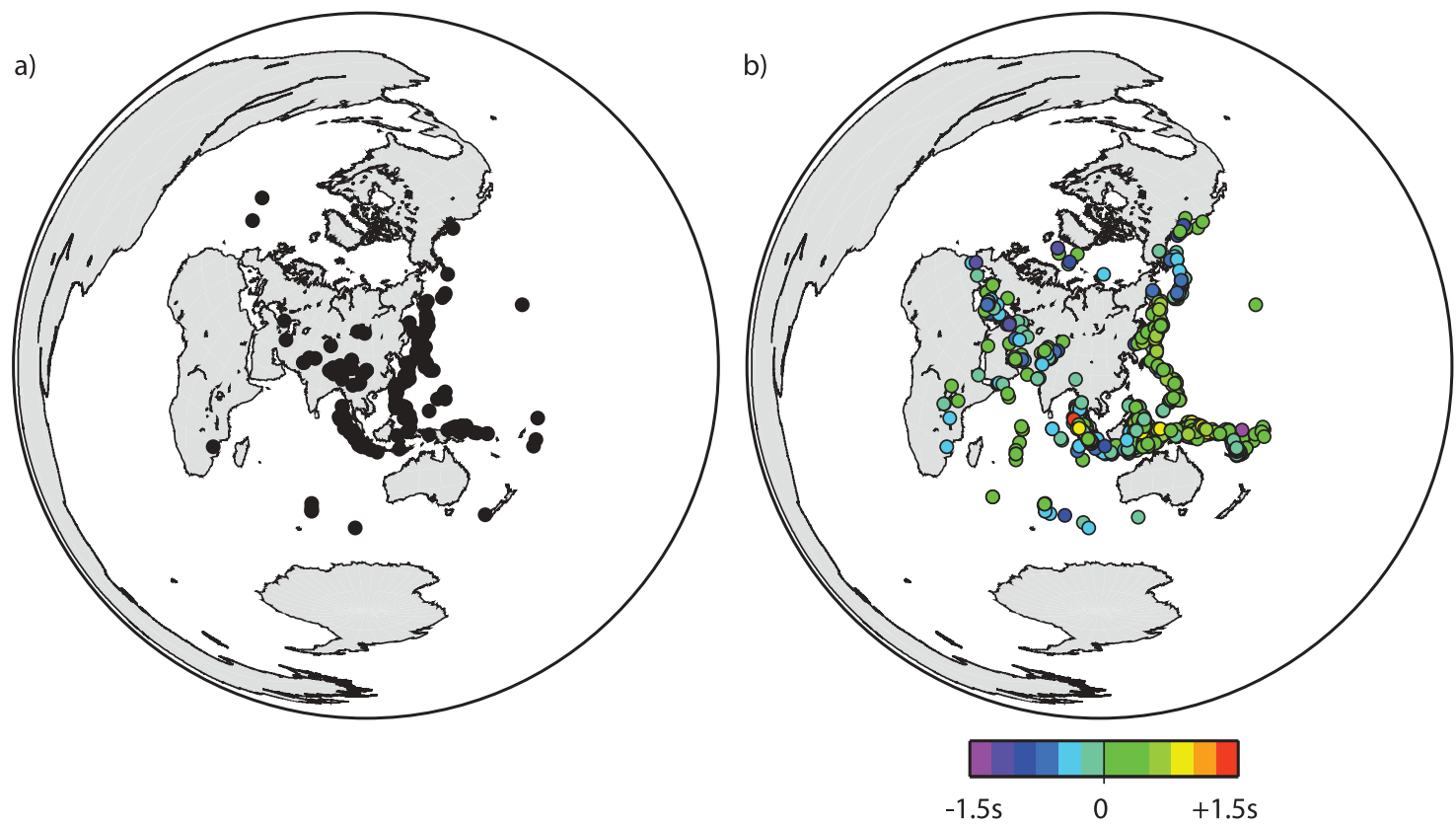

Figure 3. Event distribution. ( $\mathrm{a}$ and $\mathrm{b}$ ) The maps show the $\sim 825$ and $\sim 700$ events that provided surface wave and teleseismic shear wave arrivals, respectively. In Figure 3b, the color scale indicates the amplitude of the event correction terms determined as part of the inversion. 
a)

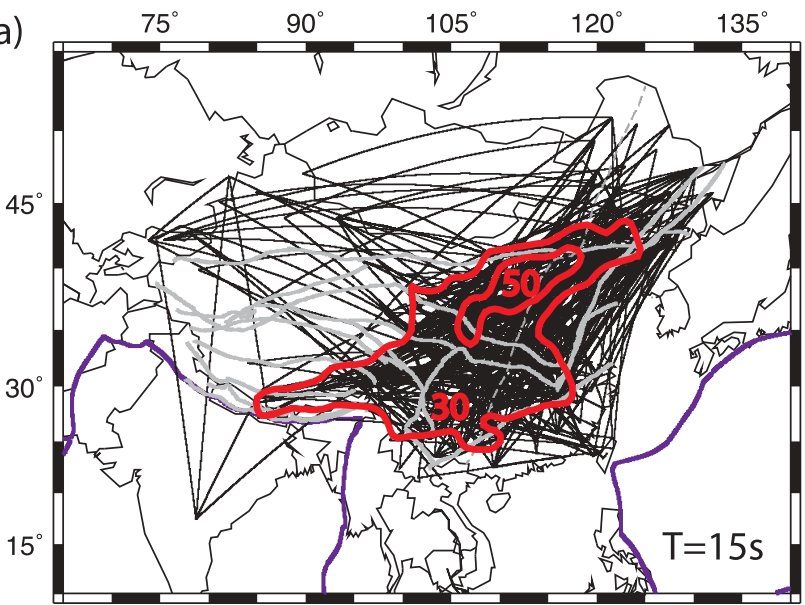

c)

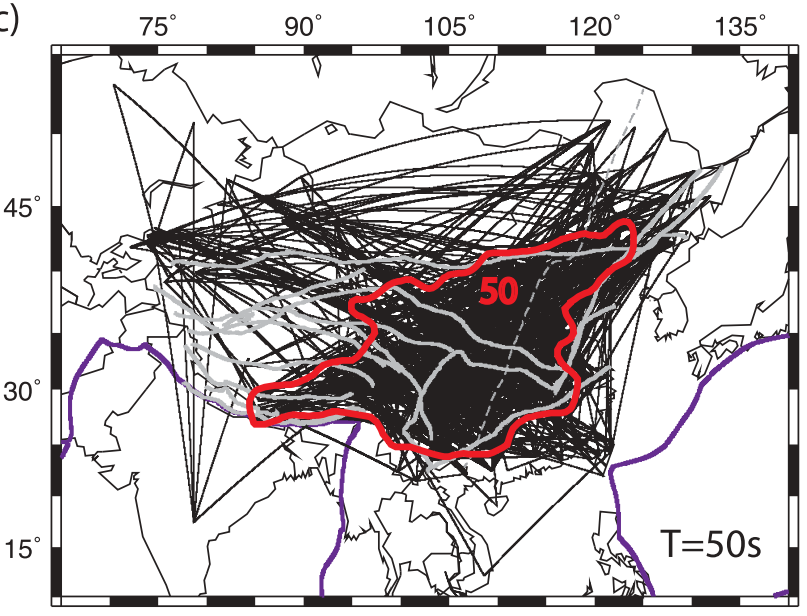

b)

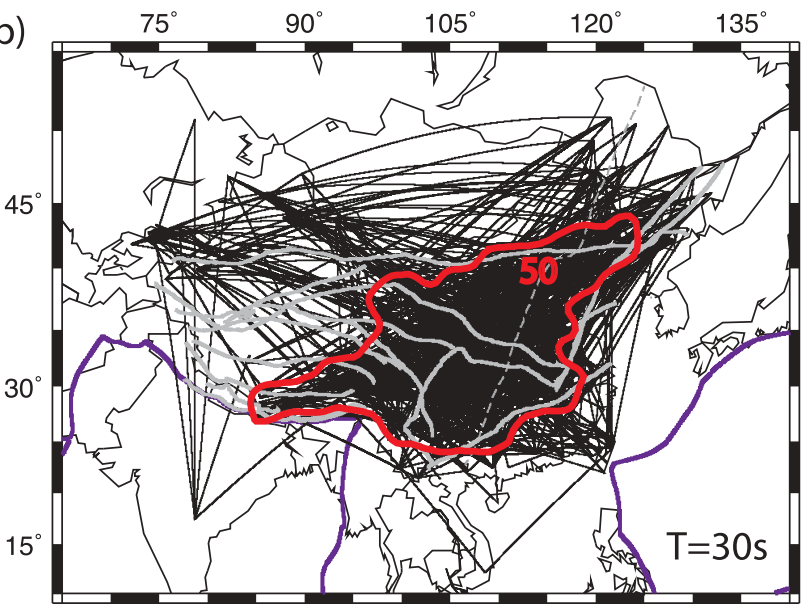

d)

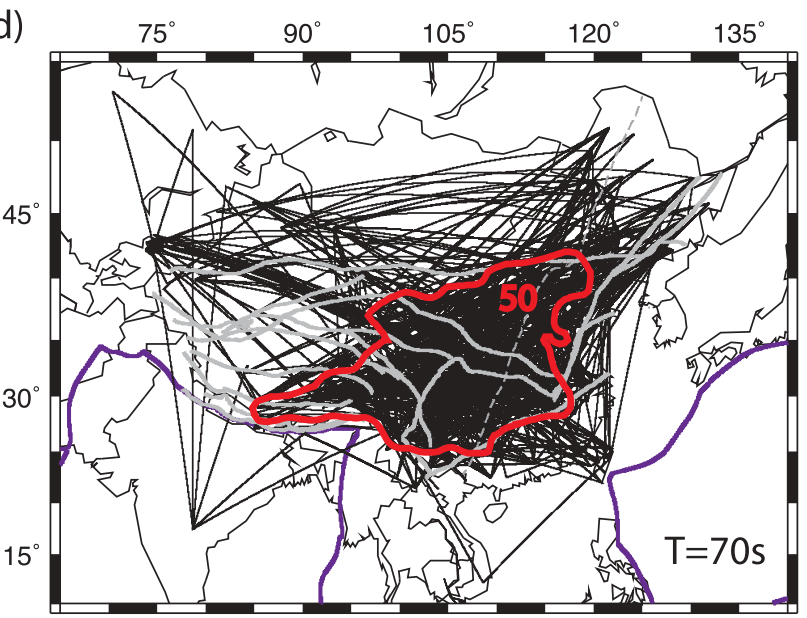

Figure 4. Raypath coverage at 4 of the 10 periods used in this study. The red contours indicate the density of raypaths in each $2^{\circ} \times 2^{\circ}$ cell. The 50 raypath contours are shown for all plots and the 30 raypath contour is also shown for the $15 \mathrm{~s}$ period map. The main faults and tectonic boundaries are shown in light gray to illustrate which of them are well covered by raypaths. Plate boundaries are shown in purple.

density calculated in $2^{\circ} \times 2^{\circ}$ cells is contoured in red to highlight the well-covered regions. The regions with 50 raypaths or more at $30 \mathrm{sec}$ and longer periods encompass the North China Craton, the Qiling-Dabie Fold Belts, the Yangtze Block, the Songpan-Ganzi and Sanjiang fold belts, the eastern Tibetan Plateau and to a lesser extent the South China Fold Belt. There are fewer rays at shorter periods. Very few raypaths were obtained for the northwestern regions. Therefore, the structure of the crust and uppermost mantle in these areas is not well constrained by surface waves and will not be discussed.

\subsection{Body Wave Data Set}

[10] The teleseismic body wave data set provides constraints on the structure of the mantle where raypaths cross one another. An approximate estimate of the minimum depth where there is resolution is the interstation distance, which ranges from a few tens to a few hundreds of kilometers in our study area (Figure 5). In addition to the data set from the CDSN and temporary deployments listed above, we included the traveltimes from Zhao et al. [2009]. The total number of stations is $\sim 1000$ including 143 stations from the CDSN.
As in the case of surface waves, northwestern China, and to a lesser degree northeastern China, have lower resolutions, as seismic stations are sparse. We selected all events with magnitude larger than 5.8 and epicentral distance ranging from $30^{\circ}$ to $80^{\circ}$. After processing and selection, the total number of traveltimes is $\sim 32,500$ from $\sim 700$ earthquakes (Figure 3b).

\section{Method}

[11] Surface and body waves have complementary properties that can be integrated to get a more complete image of the Earth's interior. Body wave tomography provides resolution where the raypaths cross each other. Consequently, teleseismic body waves recorded by large aperture seismic arrays allow illumination of the deeper structure of the mantle. Nevertheless, with a station spacing of several tens or even hundreds of $\mathrm{km}$ as that used here, teleseismic body waves offer poor constraints on the lithosphere where raypaths are subvertical. Surface waves have depth- and perioddependent sensitivity that is limited to the crust and upper mantle (Figure 2). Fundamental modes don't sample the transition zone and lower mantle as is possible with 


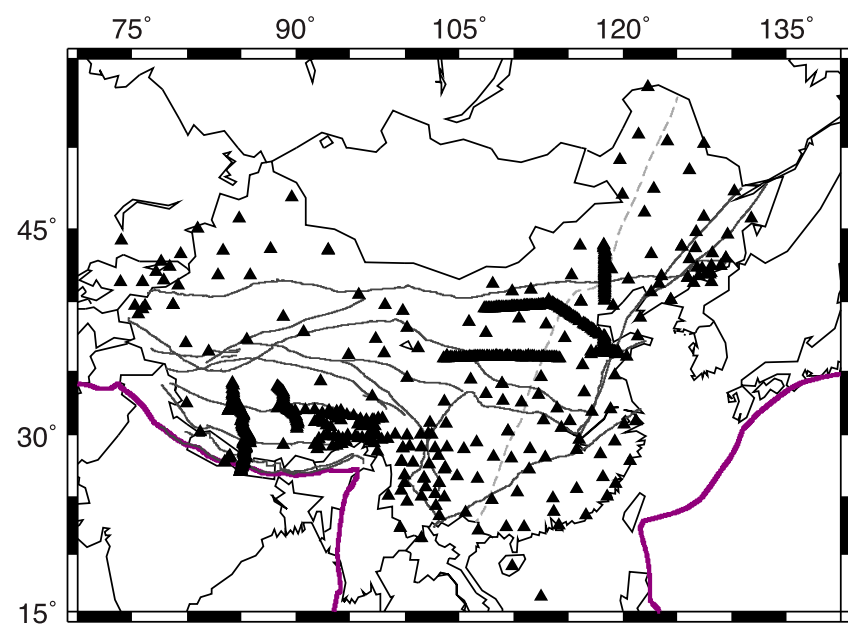

Figure 5. Distribution of the $\sim 1000$ stations that recorded the teleseismic shear wave arrivals used in this study.

teleseismic body waves, and the surface waves have lower resolution due to their lower frequency content. Nevertheless, they benefit from a good vertical resolution in the lithosphere. Therefore, a joint inversion scheme exploits the better resolution of body waves below the lithosphere, while using surface wave observations to resolve the shallow lithospheric-scale structure.

\subsection{Phase Velocities Preparation}

[12] All the waveforms with signal-to-noise ratio larger than 5 were corrected for the instrument response, converted to velocity, filtered in the frequency window $0.01-0.2 \mathrm{~Hz}$ and visually checked to select those with clear dispersive wavelet trains. Interstation phase velocity dispersion curves were measured using the method of Wu et al. [2009]. Pairs of seismograms are filtered at various periods of interest using Morlet wavelet functions and are then cross-correlated to estimate the dispersion relation. The group velocity dispersion curves were also estimated. To ensure that the estimates for the group and phase velocities were reasonable, we visually inspected them and compared them to theoretical values calculated on the basis of IASP91 with a perturbation of $\pm 10 \%$. The final set of interstation dispersion curves were then inverted for the 2D phase velocity distribution using the tomography package of Ditmar and Yanovskaya [1987] and Yanovskaya and Ditmar [1990]. Note that 3D effects related to heterogeneities are neglected and ray theory is assumed for surface waves. This last assumption seems to be reasonable as discussed by Zhou et al. [2004, 2005]. The consistency of local phase velocities (see maps in the auxiliary material) further indicates that the approach used here with its approximations is valid. ${ }^{1}$ The estimated resolution of the resulting phase velocity maps varies from $2^{\circ}$ in Eastern China where ray density is the highest to $5^{\circ}$ in Western China. We refer the reader to Pan et al. (Rayleigh wave phase velocity tomography in the Chinese continent (in Chinese), submitted to Chinese Journal of Geophysics, 2011) for a detailed description of the data preparation. The phase

${ }^{1}$ Auxiliary materials are available in the HTML. doi:10.1029/ 2011JB008349. velocity anomalies that are used in the joint inversion are obtained from the absolute phase velocities by subtracting the theoretical phase velocities calculated for a background model (IASP91). To take into account the variation in the crustal thickness across the station array, the crustal thickness of the background model was varied according to the crust model [ $L i$ et al., 2006]. Cherckerboard resolution tests are shown in Figures S1-S3 of the auxiliary material.

\subsection{Traveltimes Preparation}

[13] The body wave part of our data set is composed of relative traveltimes estimated from the transverse component of teleseismic $\mathrm{S}$ waves. All waveforms were corrected for the instrument response, converted to velocity, and visually inspected to select only high signal-to-noise arrivals. Waveforms were filtered using a $0.01-0.2 \mathrm{~Hz}$ frequency window. Traveltimes with respect to the theoretical traveltimes calculated from IASP91 were determined using the adaptive stacking method of Rawlinson and Kennett [2004]. As a test, we also estimated the delay times using the method of VanDecar and Crosson [1990] and we kept for inversion purpose only the event-station pairs that give similar estimates independently of the method. The mean of all traveltimes calculated for a given earthquake was subtracted from each individual traveltime. This way, we intend to remove the effect of anomalies located out of the model box and that affect all the raypaths originating from the same source. The body wave traveltimes were used independently to generate a shear body wave model and the resulting model is discussed by F. X. Zhang et al. (S wave structure of upper mantle beneath China and surrounding regions (in Chinese), submitted to Chinese Journal of Geophysics, 2011). Cherckerboard resolution tests are shown in Figures S1-S3 of the auxiliary material.

\subsection{Joint Inversion Scheme}

[14] The model box is a spherical cap that extends from $55^{\circ} \mathrm{E}$ to $155^{\circ} \mathrm{E}$ ( $x$ direction) and from $10^{\circ} \mathrm{N}$ to $60^{\circ} \mathrm{N}$ ( $y$ direction), with a maximum depth of $2560 \mathrm{~km}$ ( $z$ direction). The grid spacing is $1.5^{\circ}$ laterally and $40 \mathrm{~km}$ vertically. The vector of relative travel times $\delta t_{i}(i=1 \ldots N t)$ and relative phase velocities $\delta V_{\phi, i}(i=1 \ldots N \phi)$ used as constraints are linked to the components $\delta V_{S, i}(i=1 \ldots \mathrm{Nm})$ of the velocity model to be resolved through a Gram matrix G:

$$
G \times\left[\begin{array}{c}
\delta V_{S, 1} \\
\ldots \\
\delta V_{S, N m}
\end{array}\right]=\left[\begin{array}{c}
\delta t_{1} \\
\ldots \\
\delta t_{N t} \\
\delta V_{\phi, 1} \\
\ldots \\
\delta V_{\phi, N \phi}
\end{array}\right],
$$

where $N m, N t$ and $N \phi$ are the number of grid nodes, measured relative travel time and estimated phase velocity anomalies. The body wave traveltime $\delta t$ recorded for a given earthquake-station pair is related to the shear wave velocity anomalies $\delta V_{S}(x, y, z)$ at nodes $n(x, y, z)$ sampled by the associated wave using paraxial kernel theory [Dahlen et al., 2000; Hung et al., 2000, 2004]. Unlike surface waves (see discussion above), body wave wavefields are significantly affected by finite-frequency effects. The banana-doughnut-shaped kernels $K_{b}(x, y, z)$ account for the frequency- and depth-dependent width of the region to 
which teleseismic body waves are sensitive and account for wavefront healing effects. At each node $n(x, y, 0)$ of the surface of the model box, the relative phase velocities $\delta V_{\phi}\left(x, y, T_{l}\right)$ at period $T_{l}$ are related to the shear wave velocity anomalies $\delta V_{S}(x, y, z)$ at nodes $n(x, y, z)$ with $z=0, \ldots 400 \mathrm{~km}$ located immediately beneath $n(x, y, 0)$ through the surface wave vertical sensitivity kernel $K_{\phi}\left(z, T_{l}\right)$ calculated at period $T_{1}$ (Figure 2). The model box is larger than the region in which we expect to have good resolution. Using a larger model box causes any anomalies outside the model region to be accommodated in the unresolved outer region of the model space preventing pollution of the primary target region beneath the seismic network. Damping and Gaussian convolution quelling are applied. The inversion uses LSQR to iterate to a final model. Event corrections (Figure 3b) are included to account for any baseline difference between events [VanDecar and Crosson, 1990].

[15] The body and the surface wave constraints have different sensitivity. Consequently, when inverted independently, they produce models that are not necessarily similar as shown in Figure S6 of the auxiliary material. The way we integrate the two sets of constraints is by simultaneously maximizing their variance reduction while obtaining a single velocity model.

[16] The body and surface wave constraints are inverted jointly and thus need to be weighted to avoid one of the sets of constraints to be preferentially satisfied. We address this issue using the following weighting scheme for the calculation of the misfit function to minimize:

$$
\begin{aligned}
& E=\frac{p}{N t} \sum_{n=1}^{N t}\left(\frac{\delta t(n)-\sum_{x} \sum_{y} \sum_{z} K_{b}(x, y, z) \delta V_{S}(x, y, z)}{\sigma_{t}(n)}\right) \\
& +\frac{1-p}{N_{\varphi}} \sum_{x} \sum_{y} \sum_{l}\left(\frac{\delta V_{\phi}\left(x, y, T_{l}\right)-\sum_{z} K_{\phi}\left(z, T_{l}\right) \delta V_{S}(x, y, z)}{\sigma_{\varphi}\left(, x, y, T_{l}\right)}\right)
\end{aligned}
$$

$K_{b}(x, y, z)$ and $K_{\phi}\left(z, T_{l}\right)$ represent the body and surface wave sensitivity kernels described above. The number of relative traveltimes and phase velocities $N t$ and $N_{\varphi}$, as well as their respective variance $\sigma_{t}$ and $\sigma_{\varphi}$ are used to weight the different data sets in an objective fashion. The parameter $p$ ranges from 0 to 1 , and allows a manual tuning of the relative contribution of each data set (Figures S6-S9 of the auxiliary material). With $p=0.95$, the variance reductions of the two data considered independently are almost equal $(72 \%$ and $70 \%$ for the body and surface wave respectively, Figure S10 of the auxiliary material). A larger weight on the body wave contribution (p close to 1) is necessary to compensate for the higher number of nodes typically sampled by body wave raypaths. Body waves travel obliquely throughout the whole model, while surface waves sample only the upper part of the model (see sensitivity kernel on Figure 2). Note that the main features described and discussed in this study are observed for a broad range of values of $p$ (Figures $\mathrm{S} 7-\mathrm{S} 9$ of the auxiliary material).

[17] To take into account the gradual decrease in the body wave resolution toward the surface, we multiply the body wave kernels $K_{b}$ by a ramp function that equals 1 at $80 \mathrm{~km}$ depth and vanishes at the surface. Station terms are included in the body wave part of the inversion matrix to absorb traveltime delays accumulated in the upper $80 \mathrm{~km}$ and that are left unaccounted for due to the use of the ramp. The surface wave kernels $K_{\phi}$ are not modified. This way, the upper part of the model is not affected by the intrinsically poor resolution of the body waves at shallow depth. Instead it is dominated by the surface wave data set. Lowering the influence of the body wave constraints in the lithosphere is important. Our body wave only model (Figure S6 of the auxiliary material) exhibits, for example, high velocities under the eastern part of the North China Craton where most other studies based on noise correlations [Sun et al., 2010], body waves measured by high density deployments [Sun et al., 2008; Tian et al., 2009], Sn and Pn waves [Pei et al., 2007] and surface waves (Huang et al. [2009]; our own surface wave model, see Figure S6 in the auxiliary material) all show conspicuous low velocities. The fast rather than slow anomalies produced by the body wave constraints might result from vertical smearing beneath the stations where raypaths are subvertical. The inclusion of surface wave constraints thus allows us to partially solve this issue.

[18] Note that in our approach we integrate Rayleigh waves and $\mathrm{SH}$ teleseismic body waves that are polarized in distinct planes, namely the radial and transverse planes, respectively. The main motivation to do so is to increase the number of observations (we obtained far more good arrivals of SH than SV waves, the same for Rayleigh versus Love waves). This way we improve the coverage and robustness of our model. The main drawback is that anisotropy, which is common in the lithosphere and asthenosphere (see review by Savage [1999]), and that yields differences between the SH and SV velocity distribution, can lead to intrinsic discrepancies between the surface and body wave constraints used here. The effect of anisotropy is considered as second order and its study is beyond the scope of the present investigations.

\subsection{Resolution Tests}

[19] Figures 6 and 7 show checkerboard resolution tests for the joint inversion. Equivalent resolution tests were performed independently for the body and surface wave sets of data (Figures S1-S3 of the auxiliary material). The synthetic velocity anomalies were used to calculate synthetic traveltimes and phase velocities to which random noise was added. The applied noise was derived by selecting randomly from a Gaussian distribution with a standard deviation equal to $15 \%$ of the traveltime delay or phase velocity. The synthetic traveltimes and phase velocities were then combined and inverted exactly as we did for the real data. At all depths, two regions in southwestern and northwestern China are poorly resolved. Elsewhere, the resolution ranges from $3^{\circ}$ laterally and $40 \mathrm{~km}$ vertically (Figures $7 \mathrm{a}$ and $7 \mathrm{~b}$ ) to $4.5^{\circ}$ laterally and $380 \mathrm{~km}$ vertically (Figure 6f). The resolution is particularly good beneath eastern China.

\section{Results}

[20] Figure 8 shows map views of our model, named $\mathrm{CH} 11-\mathrm{S}$, at various depths in the lithosphere, asthenosphere, transition zone and lower mantle. Figures 9 and 10 emphasize the two areas where the crust and upper mantle resolution is 
Contour $50 \mathrm{~T}=30 \mathrm{~s}$

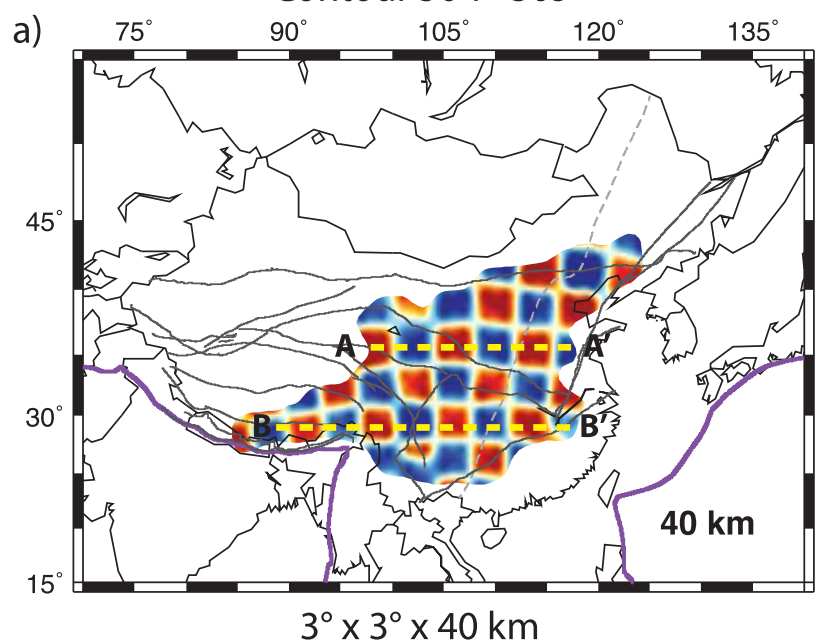

c)

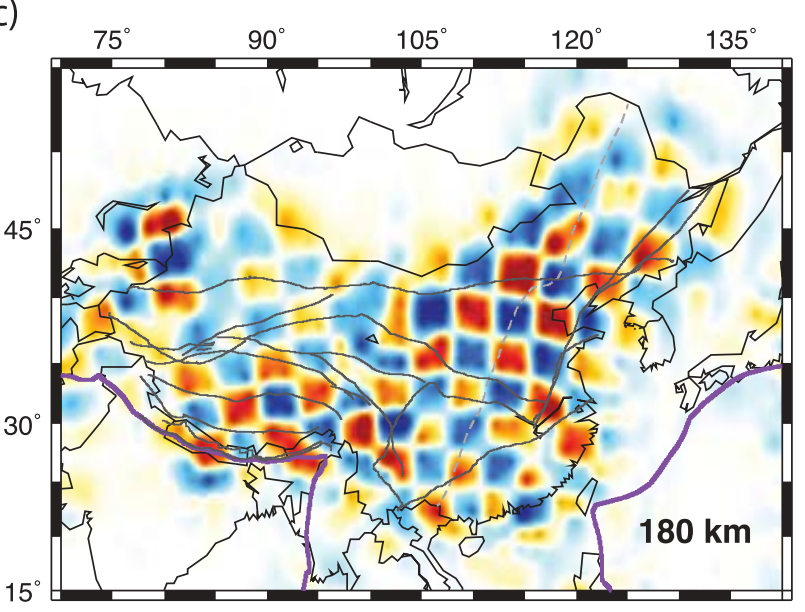

e)

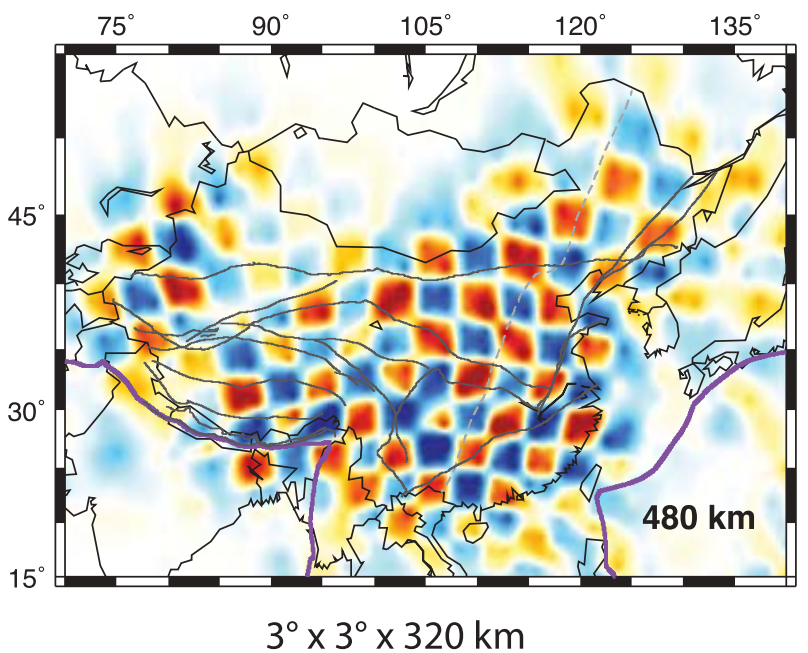

b)

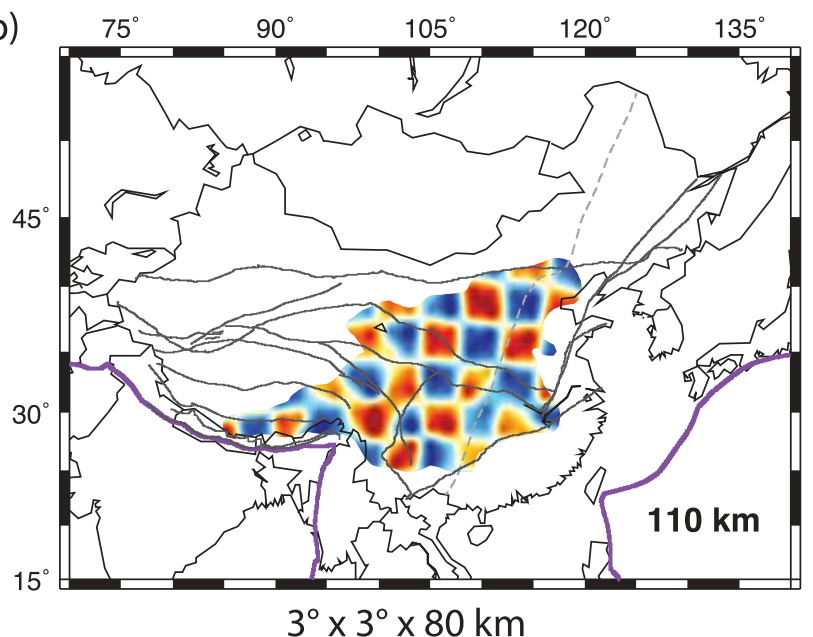

d)

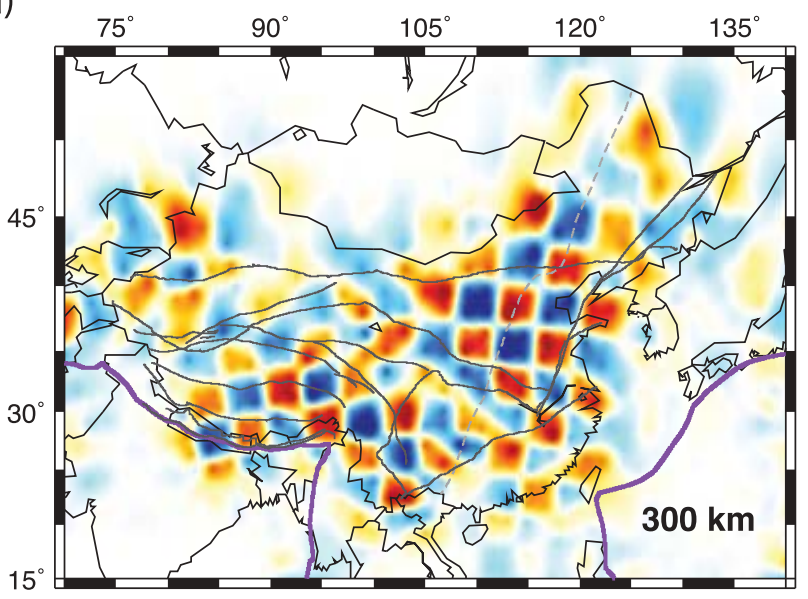

f) $3^{\circ} \times 3^{\circ} \times 120 \mathrm{~km}$

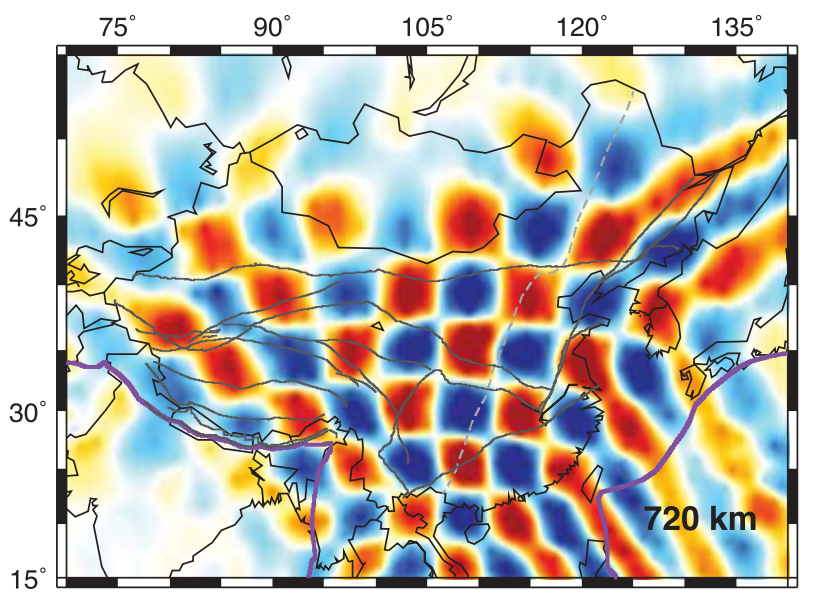

$4.5^{\circ} \times 4.5^{\circ} \times 480 \mathrm{~km}$

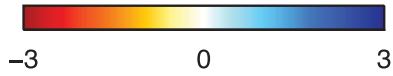

Figure 6 
a)

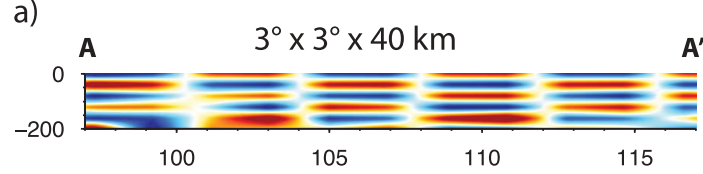

b)
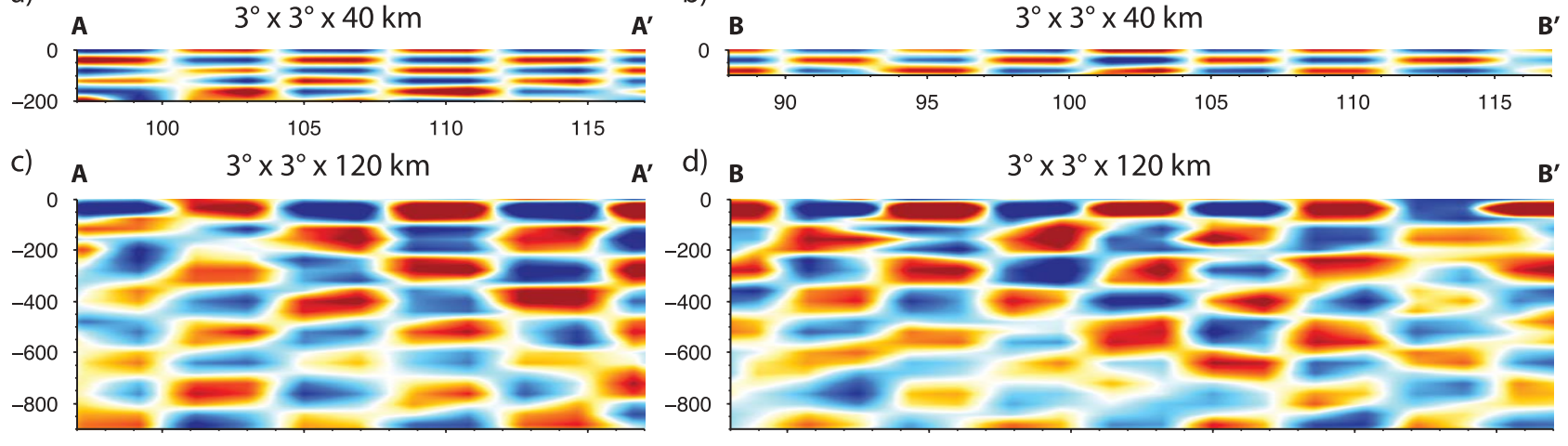

d) $B$

$3^{\circ} \times 3^{\circ} \times 120 \mathrm{~km}$

B' $^{\prime}$

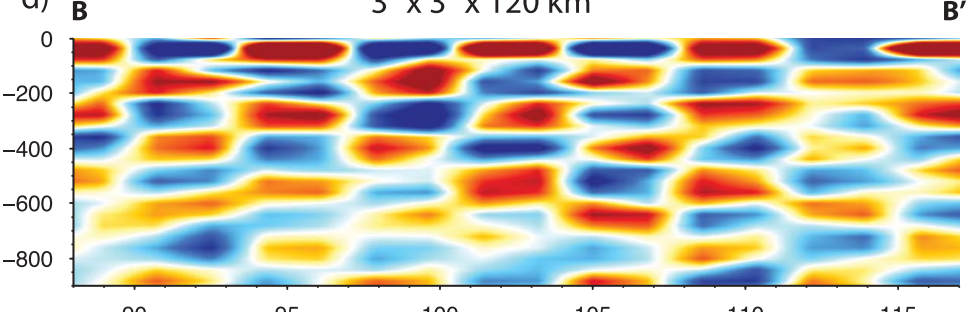

100

105

110

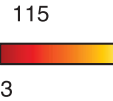

90

95

100

105

110

115

Figure 7. Checkerboard resolution tests with alternating high- and low-velocity boxes. Vertical slices through the recovered velocity structures are shown. The size of the boxes is indicated at the top of each plot. ( $\mathrm{a}$ and $\mathrm{b}$ ) The same input model that corresponds to Figure 6a. (c and d) The same input model that corresponds to Figures $6 \mathrm{c}$ and $6 \mathrm{~d}$. The locations of lines $\mathrm{AA}^{\prime}$ and $\mathrm{BB}^{\prime}$ are shown in Figure $6 \mathrm{a}$.

the best, namely eastern China and the eastern side of the Tibetan Plateau.

\subsection{North China Craton}

[21] The $\mathrm{S}$ wave velocity structure of the lithosphere and asthenosphere beneath the North China Craton shows three main domains (Figures 8a-8d) that closely correspond to the three subprovinces of the North China Craton, namely the Ordos Block, the Shanxi Rift and the North China Basin. Fast velocities are observed beneath the Ordos block ("Or," Figures $8 \mathrm{a}-8 \mathrm{~d}$ ) from the surface down to $\sim 250 \mathrm{~km}$ to the north (Figure 9b), and down to $\sim 450 \mathrm{~km}$ depth to the south (Figure 9c). Fast anomalies with a south dip beneath the Ordos Block are also observed in the $\mathrm{P}$ wave model of Li and van der Hilst [2010], although the maximum depth extent is $\sim 300 \mathrm{~km}$ in their model. In contrast, the surface wave model of Huang et al. [2009] suggests the presence of a LVZ starting at $\sim 160 \mathrm{~km}$ depth. The Shanxi Rift area exhibits slow velocities from the surface down to the top of the transition zone (Figures 9a-9c and 9e). This curtain of slow material beneath the Shanxi Rift aligns parallel to the North-south Gravity Lineament (Figures 8a and 8b). The last domain coincides with the eastern block of the North China Craton, i.e., the North China Basin. The lithosphereasthenosphere is dominantly slow down to $\sim 150 \mathrm{~km}$ depth. A flat fast feature ("F1," Figures 8c, 9b, 9c, and 9f) is imaged from 150 to $350 \mathrm{~km}$ depth with a dip toward north. Resolution tests suggest it is well resolved (Figure S4 of the auxiliary material). A similar fast anomaly is also observed in the local P model from Xu and Zhao [2009] though in the depth range of 300-400 km. The western and eastern blocks of the North China Craton are underlain by slow spots in the transition zone (Figures 8e, 9b-9d, and 9f).

\subsection{Qiling-Dabie Fold Belt}

[22] The Qiling-Dabie Fold Belt that marks the suture between the North China Craton and the South China Block exhibits slow velocities at $100 \mathrm{~km}$ depth (Figure 9a). Deeper in the upper mantle, it is either slow, or at least slower than the Ordos and Yangtze blocks (Figures 8c and 8d).

\subsection{Yangtze Craton}

[23] Fast velocities are imaged beneath the Yangtze Craton from $100 \mathrm{~km}$ depth down to the bottom of the transition zone ("Y" and "TZ1," Figures $8 \mathrm{a}-8 \mathrm{e}$ and $9 \mathrm{~d}-9 \mathrm{~g}$ ). West of the North-South Gravity Lineament, fast velocities extend upward to the surface (Figure 9a). Our S wave model thus differs from $\mathrm{P}$ wave based models [Huang and Zhao, 2006; Li and van der Hilst, 2010] where the fast anomaly of the Yangtze Block bottoms at $300 \mathrm{~km}$. Nevertheless, the resolution tests (Figure S5 of the auxiliary material) suggest that our tomographic model exhibits

Figure 6. Checkerboard resolution tests with alternating high- and low-velocity boxes. The size of the boxes is indicated at the bottom of each plot. The first and second numbers are the width (in the horizontal directions) and the third is the thickness (in depth) of the boxes. The surface wave resolution in eastern China and eastern Tibet is $\sim 3^{\circ}$ so we do not try to recover smaller boxes. The input (synthetic) velocity anomalies were $\pm 3 \%$. Horizontal slices through the recovered velocity structures are shown. The lateral and vertical resolutions improve from the bottom to the top of the model. We use boxes with a smaller depth extent at shallower depths to illustrate the increasing resolution at shallower levels. At 40 and $110 \mathrm{~km}$, the model is primarily constrained by the surface wave constraints. Therefore we only show the recovered model in the region where the averaged number of raypaths is larger than 50 in $2^{\circ} \times 2^{\circ}$ cells. For Figures $6 \mathrm{a}$ and $6 \mathrm{~b}$, we use the 50 raypaths contour at $\mathrm{T}=30 \mathrm{~s}$ and $\mathrm{T}=70 \mathrm{~s}$, respectively, as the sensitivity at these periods peak at 40 and $110 \mathrm{~km}$. Only the well-resolved region of the model is shown and discussed in this manuscript. 
vertical smearing and that it could not recover normal mantle ( $0 \%$ anomaly) sandwiched between a fast cratonic root (down to typical value of $250 \mathrm{~km}$ ) and a second high velocity feature in the transition zone. The large fast anomaly beneath the Yangtze Block seems to broaden with depth (Figures $8 \mathrm{c}-8 \mathrm{e}$ ) and exhibits a dip to the southwest and adjacent oceanic plate (Figures $9 \mathrm{~d}-9 \mathrm{~g}$ ). In contrast, its northern flank is vertical.

\subsection{South China Fold Belt}

[24] With the exception of the upper lithosphere (Figures 8a, 9f, and 9g), the mantle is dominantly slow beneath the South
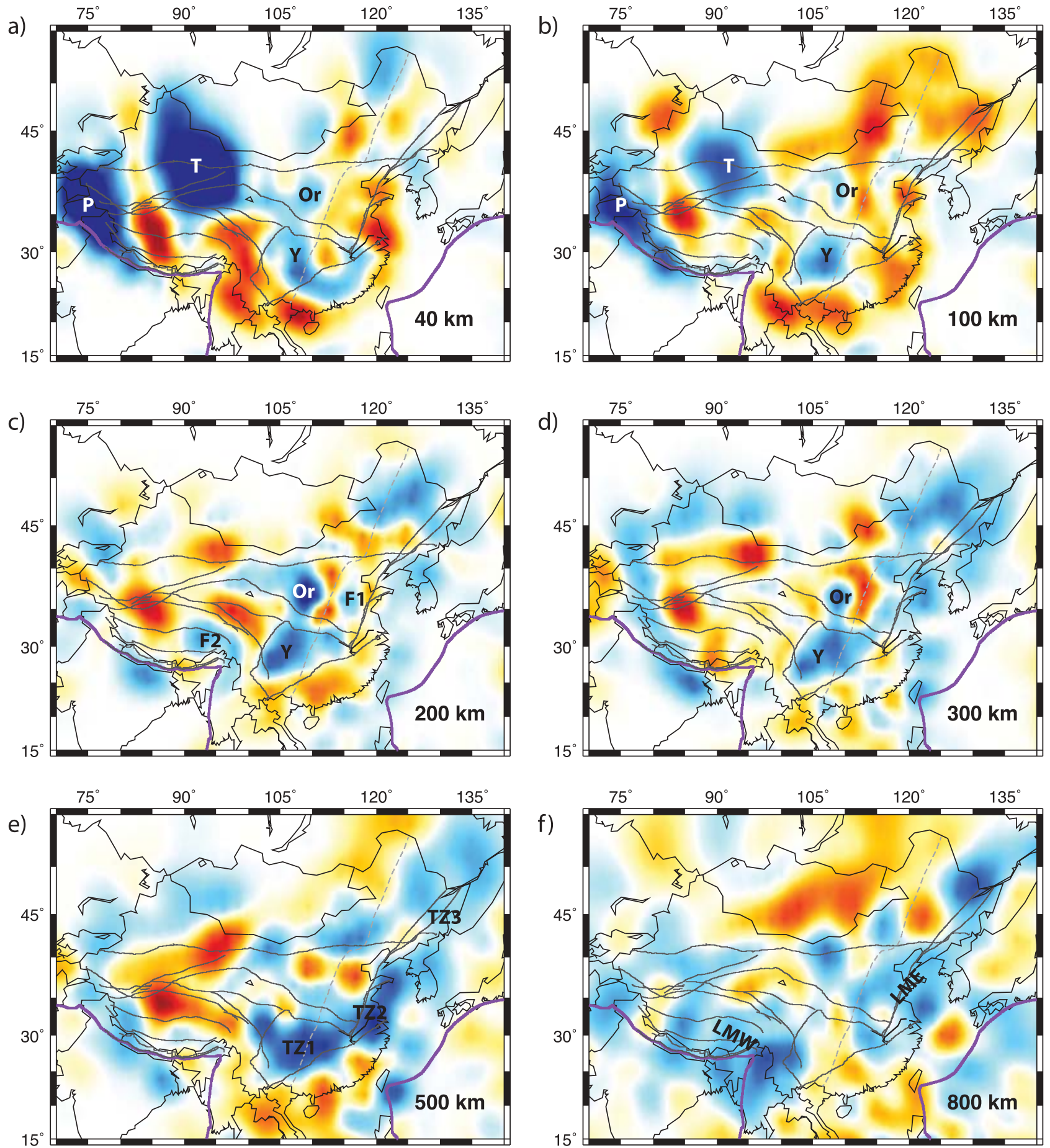

Figure 8 

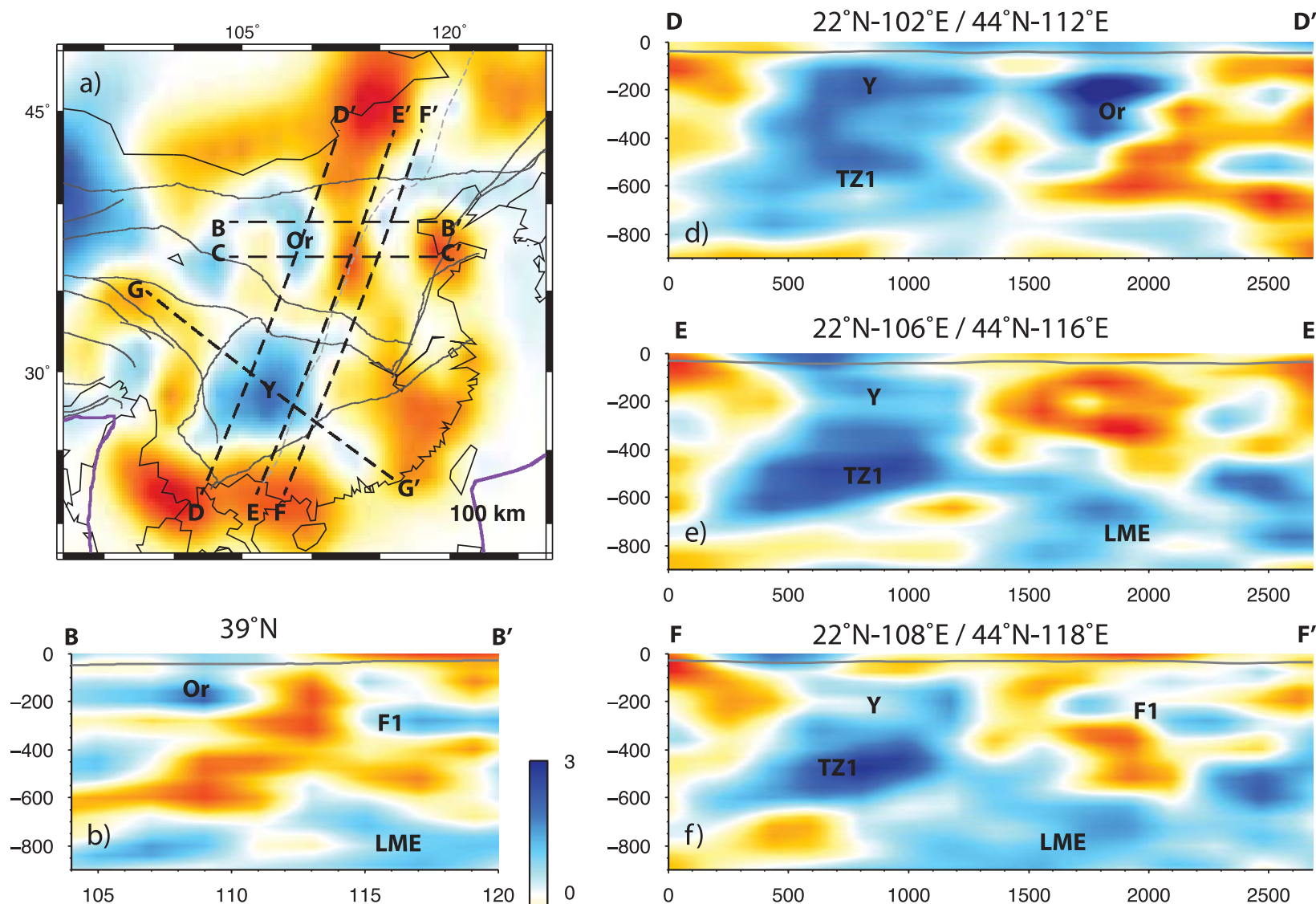

$\mathbf{B}^{\prime}$
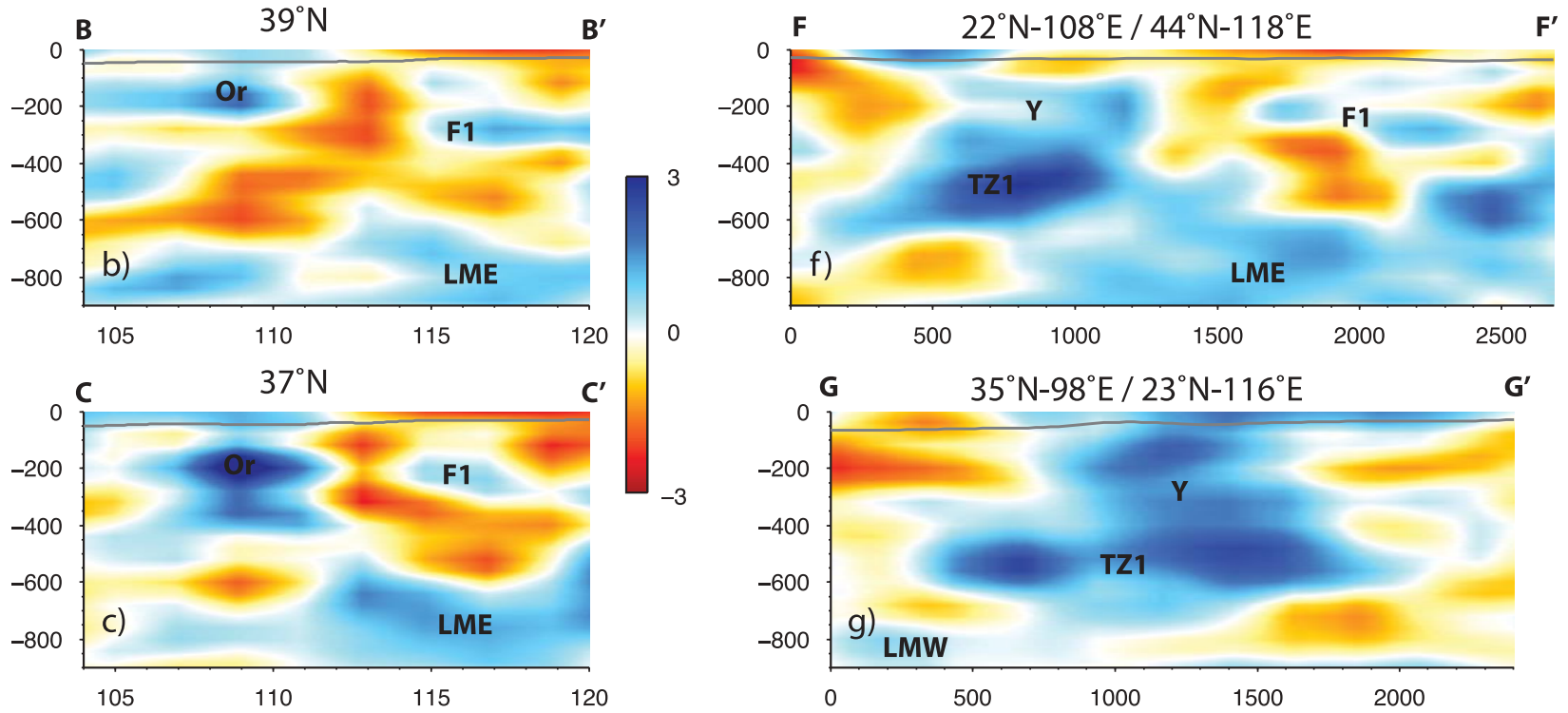

Figure 9. Vertical cross sections through CH11-S beneath eastern China. (a) Map view shows the location of cross sections. The Moho depth is indicated by the gray line on the cross sections in Figures $9 \mathrm{~b}-$ $9 \mathrm{~g}$. Fast anomalies are imaged beneath the Ordos block (Or) (b) down to $250 \mathrm{~km}$ to the north and (c) down to the top of the transition zone to the south. Slow velocities underlay the Shanxi Rift down to the transition zone (Figures 9b and 9c). The North China Basin is underlain by slow lithosphere and a slow transition zone, while fast flat features are observed in the asthenosphere (F1, Figures 9b, 9c, and 9f) and in the lower mantle (LME, Figures 9b, 9c, 9e, and 9f). (d-g) Cross sections emphasize the mantle structure beneath the Yangtze Craton and how it contrasts with that of the North China Craton. Fast anomalies underlie the Yangtze Craton down to the bottom of the transition zone $(\mathrm{Y}+\mathrm{TZ1})$, and barely overlap with LME (Figures 9e and 9f) and LMW (Figure 9g).

Figure 8. Constant depth map views of the CH11-S model at (a) 40, (b) 100, (c) 200, (d) 300, (e) 500, and (f) 800 km depth. Major faults, the North-South Gravity Lineament and tectonic and plate boundaries are shown as in Figure 1. Figures 8a and $8 \mathrm{~b}$ show recovered velocities beneath the entire region for sake of completeness. However, the western part must be considered with caution as surface wave raypaths and seismic stations are sparse there (see Figures 3 and 5-7). In particular, the amplitude of the fast anomalies around Pamir (P) and Tianshan (T) at 40 and $100 \mathrm{~km}$ are likely overestimated. Several fast anomalies are observed in the crust/upper mantle beneath the Ordos (Or) and Yangtze (Y) blocks, beneath the North China Basin (F1) and beneath eastern Tibet (F2). In the transition zone, prominent fast anomalies are seen beneath the Yangtze Craton (TZ1) and further northeast (TZ2-3). In the lower mantle, wide and fast regions are observed to the west (LMW) beneath the collision realm and to the east (LME) beneath the subduction realm. A curtain of fast anomalies is observed on the westernmost part of the model at 300 and $500 \mathrm{~km}$ depth. LMW and LME are disconnected beneath the Yangtze Craton. 

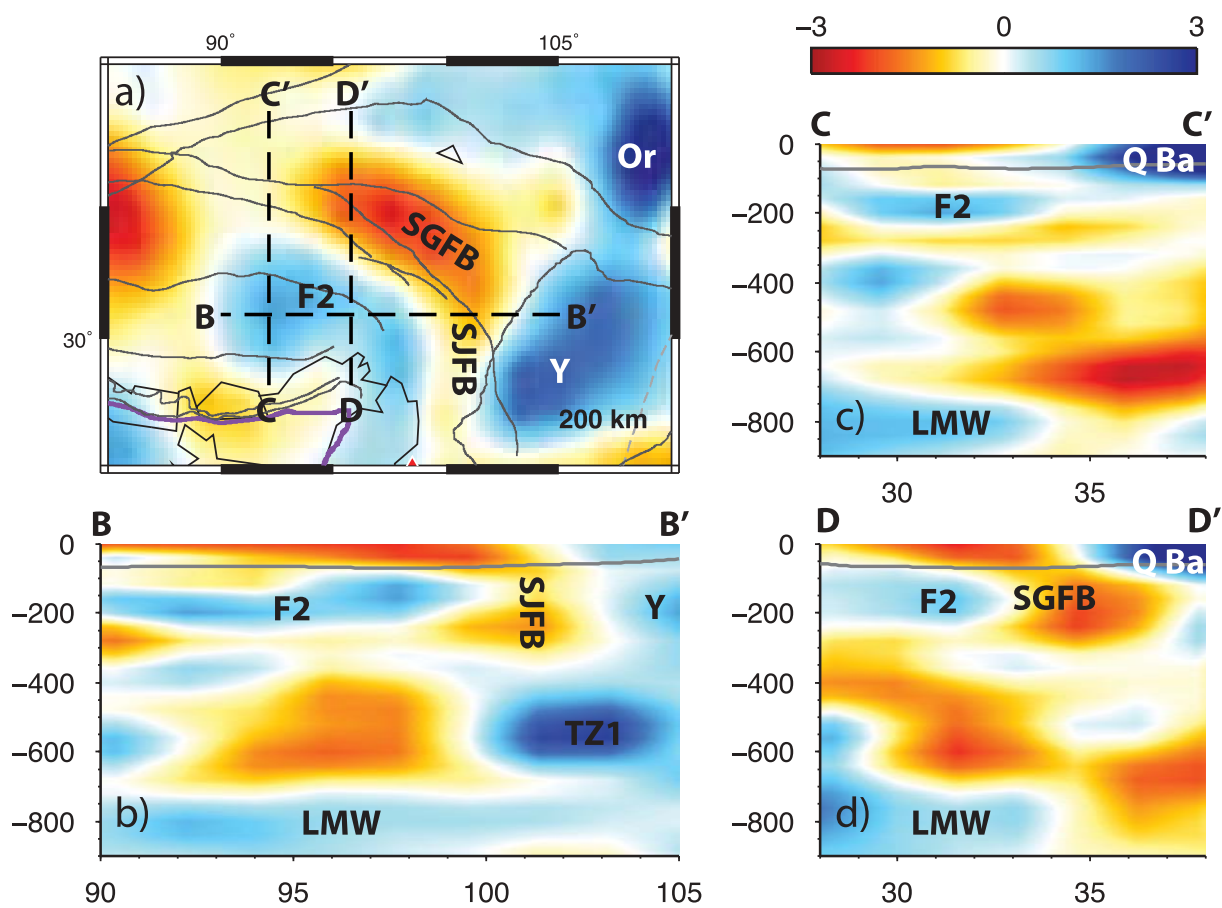

Figure 10. Vertical cross sections through CH11-S beneath eastern Tibet. (a) Map view shows the location of cross sections. The Moho depth is indicated by the gray line. (b-d) Cross sections display dominantly slow crust and mantle in the collision realm, with the exception of the fast lithosphere beneath the Qaidam Basin (Q Ba), the flat features F2 in the upper mantle and LMW in the lower mantle. To the west, F2 reaches the Qaidam Block (Figure 10c). To the east (Figure 10d) slow anomalies are observed beneath the Songpan-gansi (SGFB; Figures 10a and 10d) and Sanjiang fold belts (SJFB; Figures 10a and 10b), sandwiched between F2, the Qaidam Block, and the Yangtze Craton (Y).

China Fold Belt. Note that the upper lithosphere is less robustly resolved (Figures $5 \mathrm{a}$ and $5 \mathrm{~b}$ ). Therefore, the fast feature imaged at $40 \mathrm{~km}$ depth (Figure $8 \mathrm{a}$ ) should be considered with caution. The mantle structure of the South China Fold Belt sharply contrasts with the Yangtze Block to the northwest. Low velocities with dip toward the Yangtze Block are observed down to $250 \mathrm{~km}$ depth (Figure $9 \mathrm{~g}$ ). This trend is consistent with that of the Low Velocity Zone observed by $M a$ [1987].

\subsection{Songpan-Gansi and Sanjiang Fold Belts}

[25] Slow velocities are observed from the surface down to the top of the transition zone beneath the Songpan-Gansi Fold Belt (Figures 8a-8e) and as deep as the top of the lower mantle beneath the Sanjiang Fold Belt (Figures 8a-8f). These low velocities merge with slow anomalies beneath the Tibetan Plateau to the west and with the South China Fold Belt to the southeast (Figures $8 \mathrm{a}-8 \mathrm{e}$ ).

\subsection{Eastern Tibetan Plateau}

[26] The lithosphere is dominantly slow beneath eastern Tibet (Figures 8a, 10b-10d). A flat fast feature "F2" is observed from 150 to $250 \mathrm{~km}$ at $92^{\circ} \mathrm{E}$ (Figure 10c) and resolution tests suggest it is well resolved (Figure S4 of the auxiliary material). F2 extends northward to $34^{\circ} \mathrm{N}$ where fast anomalies are observed beneath the Qaidam Block. Further east $\left(96^{\circ} \mathrm{E}\right)$, the depth span of F2 is $50-250 \mathrm{~km}$ (Figure $10 \mathrm{~d}$ ). It extends northward to $\sim 33^{\circ} \mathrm{N}$ where the slow velocities beneath the Songpan-Gansi Fold Belt are observed. A similar fast feature is observed in the $\mathrm{P}$ wave velocity model of
Huang and Zhao [2006]. Surface wave models also suggest high $\mathrm{S}$ wave velocities in the upper mantle beneath eastern Tibet [Shapiro and Ritzwoller, 2002; Priestley et al., 2006; Lebedev and van der Hilst, 2008] In contrast, the P wave model of Li et al. [2008] shows dominantly slow velocities in the upper mantle beneath eastern Tibet. Slow velocities are also widespread beneath the Tibetan Plateau beneath $250 \mathrm{~km}$ depth down to the bottom of the transition zone (Figures $8 \mathrm{~d}$, $8 \mathrm{e}$, and 10b-10d). These low velocities seem to be surrounded by fast blocks to the east (Yangtze and Ordos) and maybe also by fast curtains to the south, west and north (Figures $8 \mathrm{c}-8 \mathrm{e}$ ). This last observation has to be taken cautiously. Even if the model still provides good large-scale resolution in the concerned areas, they are located at the limit of our station coverage.

\subsection{Lower Mantle}

[27] Two wide fast areas are imaged in the lower mantle beneath southwestern China (LMW) and eastern China (LME) (Figure 8f). These regions are separated by a slow anomaly that lies beneath the Yangtze Block, the KunlunQilian Fold Belt and the Qaidam Basin.

\section{Discussion}

\subsection{Intraplate Seismicity and Crust Upper Mantle Structure}

[28] The distribution of earthquakes with $\mathrm{M} \geq 3$ (Figure 11) correlates with several major faults, the edge of stable blocks (Ordos) and slow areas of the crust (North China Basin, 

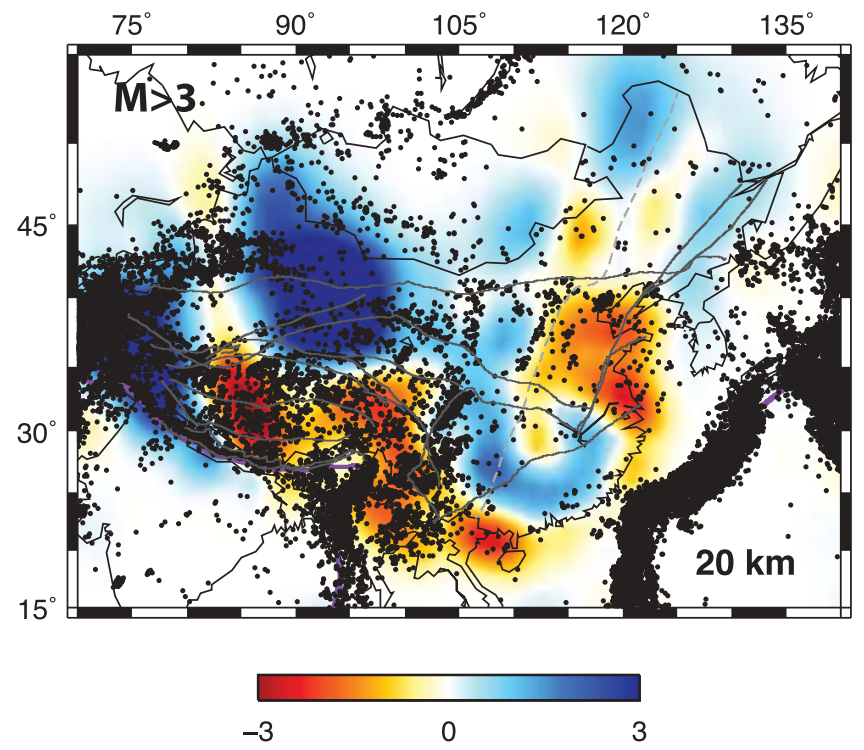

Figure 11. Comparison between seismicity with $\mathrm{M} \geq 3$ and the crustal structure as imaged in $\mathrm{CH} 11-\mathrm{S}$ beneath China. Intraplate seismicity in China dominantly occurs at crustal depth and clusters along fault systems and block boundaries.

Tibetan Plateau, Songpan-Gansi and Sanjiang Fold Belts). This correlation has been observed in previous tomographic studies [Liu et al., 1986; Huang and Zhao, 2006; Huang et al., 2009]. Almost all earthquakes in China occur in the crust. Therefore, the correlation between seismicity and crustal structures is not surprising. There is no, or little seismicity in the stable Ordos Block and Yangzte Craton. There is also no seismicity in the South China Fold Belt where the uppermost lithosphere is imaged as fast (Figures $8 \mathrm{a}, 9 \mathrm{~g}$, and 11). The absence of seismicity combined with fast lithospheric velocities may indicate that the upper lithosphere is locally strong. Nevertheless, heat flow estimates in this region are higher than for the Yangtze Craton and equivalent to that obtained in the Songpan-Gansi and Sanjiang Fold Belt [Hu et al., 2000]. A possible explanation is that basaltic underplating during Late Mesozoic subduction of the Pacific Sea Plate [Zhou and $\mathrm{Li}, 2000$ ] enhanced the lithospheric strength (and the seismic velocities) of this region.

\subsection{Decratonization and East-West Contrast in the North China Craton}

[29] The shear wave velocity structure of the North China Craton exhibits three regions that reflect the division of the North China Craton into distinct geotectonic domains, namely the stable Ordos block, the Shanxi Rift, and the North China Basin. In contrast to the aseismic and seismically fast Ordos Block, the Shanxi Rift and part of the North China Basin are seismically active (Figure 11). The reactivation of the Archean eastern part of the North China Craton has been attributed to the loss of its cratonic root sometime since Ordovician [Menzies et al., 1993; Griffin et al., 1998], either by delamination or by thermal erosion (see review of Kusky et al. [2007]). Our model does show a flat fast feature beneath the North China Basin (F1, Figures 8c, 9b, and 9c), that could represent delaminated lithosphere $[X u$ and Zhao, 2009]. If this assumption holds, F1 represents well-detached lithosphere and we would thus expect evidence of uplift in the overlying North China Basin [Göğüs and Pysklywec, 2008], which is not the case. The Phanerozoic lithosphere that replaced the Archean lithosphere is less depleted and therefore denser [Griffin et al., 1998], which puts in question the plausibility of the gravitational collapse of the Archean lithospheric root. Eclogitization of the lower crust resulting from crustal thickening during the assemblage of the North China Craton with the South China Block and the Siberia Craton could have provided negative buoyancy [Morgan, 1984]. The fast feature F1 could rather represent the remnant core of the eastern block of the North China Craton. Figure 9c emphasizes the structure of the North China Craton and shows F1 as an eroded version of the root of the Ordos Block. Its lower density (depletion) can explain why it does not sink. Thermal erosion would have been supplied by the upwelling of hot Phanerozoic mantle that we image as widespread slow anomalies beneath the Shanxi Rift and in the transition zone beneath the North China Craton (Figures 8e, 9b, and 9c). The Ordos Block is also surrounded and underlain by slow material and shows possible evidence of reactivation as the encroachment of seismicity on its northeastern edge (Figure 11) where its root is the thinnest (Figures 9b and 9d), and heat flow comparable to that of the eastern block and higher than that of the Yangtze Craton [Hu et al., 2000].

\subsection{Slab Graveyard Beneath China and Lithospheric Stability}

[30] Aside from the obvious effects of convergence directly along the collision and subduction realms, associated material injection into the transition zone and the lower mantle may also play a role in the dynamics of the overlying lithosphere and asthenosphere. Several fast features are observed both in the transition zone (TZ1-3) and in the lower mantle (LMW and LME). Those beneath eastern and northeastern China (TZ2-3) have been linked to the currently subducting Pacific and Philippines Sea slabs [Bijwaard et al., 1998; Huang and Zhao, 2006; Li and van der Hilst, 2010]. The southernmost TZ1 could be lithosphere left after the South China Block-North China Craton collision [Lebedev and Nolet, 2003] or a stagnant slab relic from the Mesozoic Pacific Sea Plate [Li and van der Hilst, 2010]. The wide fast regions beneath the collision (LMW) and subduction (LME) realms are likely slab material from the TethysIndian and Pacific slabs that has already sunk into the lower mantle.

[31] The distribution of stable versus unstable regions in China seems related to some extent to the structure of the transition zone and lower mantle. The stable Yangtze Craton, and to less extent the Ordos block, do not overlap with lower mantle anomalies LMW and LME. TZ1 coincides with the Yangtze Craton and also with the gap between LMW and LME. The motion or stagnancy of these fast bodies could promote or inhibit mantle convection and tectonism. First, the foundering of slab fragments (LMW and LME) from the transition zone into the lower mantle is likely to trigger upper mantle instability by forcing mass displacement. In particular, the slow anomalies located above LME (Figures 9a and 9b) and LMW (Figures 10b-10d) could have been emplaced to fill the space left by these sinking slab fragments. The transition zone beneath China seems to 
be an important mechanical barrier that apparently exerts a substantial control on the mantle structure and dynamics. This is indicated by the presence of several stagnant slabs in the transition zone and also by the many velocity contrasts (high to low or vice versa) occurring at the 410 and $660 \mathrm{~km}$ discontinuities (Figures 9 and 10). Corner flow and dehydration related to the penetration of the stagnant slab (TZ2-3) in the transition zone is also thought to contribute to the emplacement of slow mantle beneath eastern China (Figures $8 \mathrm{~b}$ and $8 \mathrm{c}$ ) and to promote tectonism [Huang and Zhao, 2006]. Second, the fast feature TZ1, whatever its nature, could promote the stability of the overlying mantle indicated by a lower level of seismicity in the crust (Figure 11) and lower heat flow [Hu et al., 2000]. With the caveat of resolution limitation pointed out in 5.3, the fast mantle imaged from $410 \mathrm{~km}$ to $250-300 \mathrm{~km}$ beneath the Yangtze Block could represent mantle that has remained or became cooler and more viscous than the surrounding areas owing to its being sandwiched between TZ1 and the cratonic lithosphere from the Yangtze Block.

\subsection{Upper Mantle Beneath Eastern Tibet Region}

[32] The horizontal feature F2 could be the Indian Slab underthrusting the Tibetan blocks. Surprisingly, we don't observe any clear continuation of F2 northward or downward (Figures 10c and 10d) that would represent the subducted Indian Sea Slab. This may indicate that the Indian Sea Slab detached and sank into the lower mantle (perhaps anomaly LMW) while the continental lithosphere (F2) stalled beneath the Tibetan lithosphere because of its buoyancy. Nevertheless, under this scenario and owing to the southeastward absolute motion of the Eurasian Plate during the Cenozoic [Honza and Fujioka, 2004], we would expect any subducted Indian Sea Slab fragment to lie northwest of the northern edge of the continental Indian Slab stalled beneath the Tibetan Plateau. In contrast, LMW is located beneath F2, suggesting these structures are independent. Alternatively, F2 could be Eurasian lithosphere. F2 spans the three blocks of the Tibetan Plateau (Qiangtang, Lhasa, Himalaya) and its depth extent is $50-250 \mathrm{~km}$. In the context of India-Eurasia collision, the emplacement of lithospheric material at this depth could have resulted either from lithospheric contraction and thickening or from lower crust and underlying mantle delamination. The northernmost extent of F2 actually coincides with the northern boundary of the Qiangtang Block where the geochemistry of the volcanic rock is suggestive of foundered lower crust [Liu et al., 2008]. Eclogitization of the lower crust through crustal contraction and thickening is likely to happen in the context of India-Eurasia convergence and would provide negative buoyancy to trigger lithospheric instability. All these observations are consistent with F2 being delaminated lithosphere of the Qiangtang-Lhasa blocks. The lateral flow of hot asthenospheric material to fill the space left between the crust and the delaminated lithosphere would heat the crust, explaining the widespread low velocity observed above F2. In all scenarios, the continental nature of F2 (Indian lithosphere or Qiangtang-Lhasa lithosphere) and associated low density and buoyancy would account locally for the low gravity and high topography.

[33] On a large scale, the mantle is dominantly slow beneath Western China. Slow mantle velocity beneath China may result partially from the injection of fluids through continuous subduction during the Phanerozoic. The slow mantle anomalies beneath western China appear to be surrounded by fast, potentially strong blocks: the parabola shaped fast curtain to the west, the Tarim Craton to the north, the collision realm and Bhurma slab to the south, and the Ordos and Yangtze blocks to the east (Figures 8b-8e). There is a connection along the Sanjiang Fold Belt (Figure 10b) between slow anomalies beneath eastern Tibet and terrain to the southeast (Figures $8 \mathrm{a}-8 \mathrm{c}$ ), i.e., in the direction of the crust motion beneath the Sanjiang Fold Belt with respect to the South China Block [Wang et al., 2001; Zhang et al., 2004] and also in the proposed direction of extrusion induced by India-Eurasia convergence. This observation suggests that part of the slow, likely low viscosity, mantle beneath Tibet that was pushed by material injection in the collision realm escaped to the southeast that was the only "open" adjacent region. The slow velocities observed consistently from the surface down to $\sim 350 \mathrm{~km}$ depth suggest that the extrusion process involved both the crust and the mantle. Nevertheless, the lateral extent of the low velocity channel beneath the Sanjiang Fold Belt between the slow anomalies of the Tibetan Plateau and that of the South China Fold Belt is small $\left(\sim 2-3^{\circ}\right)$ and could probably have not enabled massive transfer of material, such as the emplacement of the widespread slow mantle beneath the South China Fold Belt. We can thus speculate that the apparent confinement of slow, presumably hot mantle beneath western China may have had an impact on regional tectonics, by promoting convection in the asthenosphere, thermally reducing the viscosity of the lithosphere and generating buoyancy and uplift.

\section{Summary}

[34] We combined teleseismic $\mathrm{S}$ wave traveltimes and surface wave phase velocities measured at stations of the CDSN and temporary deployments across China to obtain a regional tomographic model of the shear wave velocity distribution. The main observations and implications made on the basis of our CH11-S model are as follows:

[35] 1. The lithosphere and asthenosphere beneath China exhibit largely slow velocities. The exceptions include the stable Ordos and Yangtze blocks that are underlain by fast mantle anomalies that extend as deep as the top of the transition zone, a fast anomaly from 150 to $350 \mathrm{~km}$ depth beneath the North China Basin and a flat fast feature beneath eastern Tibet from 50 to $250 \mathrm{~km}$ depth.

[36] 2. The fast anomaly observed beneath the North China Basin could represent the relic cratonic root of the eastern block of the North China Craton. Alteration of the lithospheric root could have resulted from either thermal erosion or lithospheric instability that occurred at some point since the Ordovician. Our model does not allow favoring either of these two models.

[37] 3. The fast anomaly observed beneath eastern Tibet could represent the Indian continental lithosphere stalled beneath the Eurasian Plate. Nevertheless, there are also indications that this fast feature could be delaminated lithosphere from the contracted and thickened Lhasa and Qiangtang blocks that make up the Tibetan Plateau. 
[38] 4. A large fast and flat feature is imaged in the transition zone beneath the Yangtze Craton and may contribute to its stability by isolating it from convection in the surrounding mantle.

[39] 5. Large fast regions in the lower mantle underlie the tectonically active India-Eurasia collision realm to the west and the Pacific-Philippines subduction realm to the east. These fast features are probably oceanic slab fragments that have already sunk into the lower mantle. By forcing mantle displacement, they may have promoted mantle convection in these regions, lithospheric instabilities and extensional/ contractional deformations.

[40] 6. The mantle is dominantly slow beneath western China and is surrounded by fast and presumably strong lithospheric blocks. Limited mantle escape could have occurred to the southeast beneath the Sanjiang Fold Belt where low velocities are observed throughout the mantle to the transition zone. The confinement of slow and hot mantle beneath western China could account for part of the uplift observed in this region and also promote internal deformation of the lithosphere.

[41] Acknowledgments. Waveform data recorded by the stations of the China National Seismic Network were provided by the Data Management Center at the Institute of Geophysics, China Earthquake Administration. We also thank the IRIS DMC for data distribution. Zhao Liang provided $\mathrm{S}$ wave travel times and constructive comments that helped improving this manuscript. Fred Pollitz shared his codes to calculate surface wave sensitivity kernels. We also thank two anonymous reviewers who contributed to improve the quality of this manuscript. Most figures were generated using the Generic Mapping Tool [Wessel and Smith, 1998]. This work was supported by the National Science Foundation, a UC-National Laboratory Research program grant and the National Natural Science Foundation of China (grant 40774039).

\section{References}

An, M., M. Feng, and Y. Zhao (2009), Destruction of lithosphere within the north China craton inferred from surface wave tomography, Geochem. Geophys. Geosyst., 10, Q08016, doi:10.1029/2009GC002562.

Bijwaard, H., W. Spakman, and E. R. Engdahl (1998), Closing the gap between regional and global travel time tomography, J. Geophys. Res., 103, 30,055-30,078, doi:10.1029/98JB02467.

Dahlen, F. A., S. H. Hung, and G. Nolet (2000), Fréchet kernels for finitefrequency traveltimes-I. Theory, Geophys. J. Int., 141, 157-174, doi:10.1046/j.1365-246X.2000.00070.x.

Ditmar, P. G., and T. B. Yanovskaya (1987), Generalization of Backus Gilbert method for estimation of lateral variations of surface wave velocities, Phys. Solid Earth, 23, 470-477.

Göğüs, O., and R. N. Pysklywec (2008), Near surface diagnostics of dripping or delaminating lithosphere, J. Geophys. Res., 113, B11404, doi:10.1029/2007JB005123.

Griffin, W. L., A. Zhang, S. Y. O'Reilly, and C. G. Ryan (1998), Phanerozoic evolution of the lithosphere beneath the Sino-Korean craton, in Mantle Dynamics and Plate Interactions in East Asia, Geodyn. Ser., vol. 27, edited by M. F. J. Flower et al., pp. 107-126, AGU, Washington, D. C.

Honza, E., and K. Fujioka (2004), Formation of arcs and back-arc basins inferred from the tectonic evolution of Southeast Asia since the Late Cretaceous, Tectonophysics, 384, 23-53, doi:10.1016/j.tecto.2004.02.006.

$\mathrm{Hu}, \mathrm{S} ., \mathrm{L}$. He, and J. Wang (2000), Heat flow in the continental area of China: A new data set, Earth Planet. Sci. Lett., 179, 407-419, doi:10.1016/S0012-821X(00)00126-6.

Huang, J., and D. Zhao (2006), High-resolution mantle tomography of China and surrounding regions, J. Geophys. Res., 111, B09305, doi:10.1029/2005JB004066.

Huang, Z., W. Su, Y. Peng, Y. Zheng, and H. Li (2003), Rayleigh wave tomography of China and adjacent regions, J. Geophys. Res., 108(B2), 2073, doi:10.1029/2001JB001696.

Huang, Z., H. Li, Y. Zheng, and Y. Peng (2009), The lithosphere of North China Craton from surface wave tomography, Earth Planet. Sci. Lett., 288, 164-173, doi:10.1016/j.eps1.2009.09.019.
Hung, S. H., F. A. Dahlen, and G. Nolet (2000), Fréchet kernels for finitefrequency traveltimes-II. Examples, Geophys. J. Int., 141, 175-203, doi:10.1046/j.1365-246X.2000.00072.x.

Hung, S. H., Y. Shen, and L. Y. Chiao (2004), Imaging seismic velocity structure beneath the Iceland hot spot: A finite frequency approach, J. Geophys. Res., 109, B08305, doi:10.1029/2003JB002889.

Kusky, T. M., B. F. Windley, and M.-G. Zhai (2007), Tectonic evolution of the North China Block: From orogen to craton to orogen, Geol. Soc. Spec. Publ., 280, 1-34, doi:10.1144/SP280.1.

Lebedev, S., and G. Nolet (2003), Upper mantle beneath Southeast Asia from S velocity tomography, J. Geophys. Res., 108(B1), 2048, doi:10.1029/2000JB000073.

Lebedev, S., and R. D. van der Hilst (2008), Global upper-mantle tomography with the automated multi-mode surface and S waveforms, Geophys. J. Int., 173, 505-518, doi:10.1111/j.1365-246X.2008.03721.x.

Li, C., and R. D. van der Hilst (2010), Structure of the upper mantle and transition zone beneath Southeast Asia from traveltime tomography, J. Geophys. Res., 115, B07308, doi:10.1029/2009JB006882.

Li, C., R. D. Van der Hilst, A. S. Meltzer, and E. R. Engdahl (2008), The subduction of Indian lithosphere beneath the Tibetan plateau and Burma, Earth Planet. Sci. Lett., 274, 157-168, doi:10.1016/j.epsl.2008.07.016.

Li, S., W. D. Mooney, and J. Fan (2006), Crustal structure of mainland China from deep seismic sounding data, Tectonophysics, 420, 239-252, doi:10.1016/j.tecto.2006.01.026.

Liu, F., K. Qu, H. Wu, Q. Li, J. Liu, and G. Hu (1986), Seismic tomography of the north China region (in Chinese), Chin. J. Geophys., 29, 442-449.

Liu, G. (1987), The Cenozoic rift system of the North China Plain and the deep internal process, Tectonophysics, 133, 277-285, doi:10.1016/00401951(87)90270-8.

Liu, M., X. Cui, and F. Liu (2004), Cenozoic rifting and volcanism in eastern China: A mantle dynamic link to the Indo-Asian collision?, Tectonophysics, 393, 29-42, doi:10.1016/j.tecto.2004.07.029.

Liu, S., et al. (2008), Cenozoic high Sr/Y volcanic rocks in the Qiangtang terrane, northern Tibet: Geochemical and isotopic evidence for the origin of delaminated lower continental melts, Geol. Mag., 145, 463-474, doi: $10.1017 / \mathrm{S} 0016756808004548$.

Ma, X. Y. (1987), Lithospheric dynamics map of China and adjacent seas, 1:4,000,000, China Geol. Publ. House, Beijing.

Ma, X., G. Liu, and J. Su (1984), The structure and dynamics of the continental lithosphere in north-northeast China, Ann. Geophys., 2, 611-620.

Masters, G., S. Johnson, G. Laske, H. Bolton, and J. H. Davies (1996), A shear-velocity model of the mantle, Philos. Trans. R. Soc. A, 354, 1385-1411, doi:10.1098/rsta.1996.0054.

Mégnin, C., and B. Romanowicz (2000), The 3D shear velocity structure of the mantle from the inversion of body, surface and higher mode waveforms, Geophys. J. Int., 143, 709-728, doi:10.1046/j.1365-246X.2000.00298.x.

Meng, Q.-R. (2003), What drove late Mesozoic extension of the northern China-Mongolia tract?, Tectonophysics, 369, 155-174, doi:10.1016/ S0040-1951(03)00195-1.

Menzies, M. A., W. Fan, and M. Zhang (1993), Paleozoic and Cenozoic lithoprobes and the loss of $>120 \mathrm{~km}$ of Archaean lithosphere, SinoKorean craton, China, Geol. Soc. Spec. Publ., 76, 71-81, doi:10.1144/ GSL.SP.1993.076.01.04.

Menzies, M., Y. Xu, H. Zhang, and W. Fan (2007), Integration of geology, geophysics and geochemistry: A key to understanding the North China Craton, Lithos, 96, 1-21, doi:10.1016/j.lithos.2006.09.008.

Metcalfe, I. (2006), Palaeozoic and Mesozoic tectonic evolution and palaeogeography of East Asian crustal fragments: The Korean Peninsula in context, Gondwana Res., 9, 24-46, doi:10.1016/j.gr.2005.04.002.

Morgan, P. (1984), The thermal structure and thermal evolution of the continental lithosphere, Phys. Chem. Earth, 15, 107-193, doi:10.1016/00791946(84)90006-5.

Obrebski, M. J., R. Allen, F. Pollitz, and S.-H. Hung (2011), Lithosphereasthenosphere interaction beneath the western US from the joint inversion of body wave travel times and surface waves phase velocities, Geophys. $J$. Int., in press.

Pei, S., J. Zhao, Y. Sun, Z. Xu, S. Wang, H. Liu, C. A. Rowe, M. Nafi Toksoz, and X. Gao (2007), Upper mantle seismic velocities and anisotropy in China determined through Pn and Sn tomography, J. Geophys. Res., 112, B05312, doi:10.1029/2006JB004409.

Priestley, K., E. Debayle, D. McKenzie, and S. Pilidou (2006), Upper mantle structure of eastern Asia from multimode surface waveform tomography, J. Geophys. Res., 111, B10304, doi:10.1029/2005JB004082.

Rawlinson, N., and B. L. N. Kennett (2004), Rapid estimation of relative and absolute delay times across a network by adaptive stacking, Geophys. J. Int., 157, 332-340, doi:10.1111/j.1365-246X.2004.02188.x.

Ren, J., C. Jiang, Z. Zhang, and D. Qin (1987), Geotectonic Evolution of China, Springer, Hong Kong. 
Ren, J., K. Tamaki, S. Li, and J. Zhang (2002), Late Mesozoic and Cenozoic rifting and its dynamic setting in Eastern China and adjacen areas, Tectonophysics, 344, 175-205, doi:10.1016/S0040-1951(01) $00271-2$

Savage, M. K. (1999), Seismic anisotropy and mantle deformation: What have we learned from shear wave splitting?, Rev. Geophys., 37(1), 65-106, doi:10.1029/98RG02075.

Shapiro, N. M., and M. H. Ritzwoller (2002), Monte-Carlo inversion for a global shear-velocity model of the crust and upper mantle, Geophys. J. Int., 151, 88-105, doi:10.1046/j.1365-246X.2002.01742.x.

Sun, X., X. Song, S. Zheng, Y. Yang, and M. Ritzwoller (2010), Three dimensional shear velocity structure of crust and upper mantle in China from ambient noise surface wave tomography, Earth Sci., 23, 449-463, doi:10.1007/s11589-010-0744-4.

Sun, Y., M. N. Toksoz, S. Pei, D. Zhao, F. D. Morgan, and A. Rosca (2008), S wave tomography of the crust and uppermost mantle in China, J. Geophys. Res., 113, B11307, doi:10.1029/2008JB005836

Tapponnier, P., G. Peltzer, A. Y. Le Dain, R. Armijo, and P. Cobbold (1982), Propagating extrusion tectonics in Asia: New insights from simple experiments with plasticine, Geology, 10, 611-616, doi:10.1130/ 0091-7613(1982)10<611:PETIAN $>2.0 . \mathrm{CO} ; 2$.

Tian, Y., D. Zhao, R. Sun, and J. Teng (2009), Seismic imaging of the crust and upper mantle beneath the North China Craton, Phys. Earth Planet Inter., 172, 169-182, doi:10.1016/j.pepi.2008.09.002.

Tian, Z. Y., P. Han, and K. D. Xu (1992), The Mesozoic-Cenozoic East China rift system, Tectonophysics, 208, 341-363, doi:10.1016/00401951(92)90354-9.

VanDecar, J. C., and R. S. Crosson (1990), Determination of teleseismic relative phase arrival times using multi-channel cross-correlation and least squares, Bull. Seismol. Soc. Am., 80, 150-169.

Wang, Q., et al. (2001), Present day crustal deformation in China constrained by Global Positioning System (GPS) measurements, Science, 294, 574-577, doi:10.1126/science.1063647.

West, M., W. Gao, and S. Grand (2004), A simple approach to the joint inversion of seismic body and surface waves applied to the southwest U.S, Geophys. Res. Lett., 31, L15615, doi:10.1029/2004GL020373.

Wu, Q. J., X. F. Zheng, J. T. Pan, F. X. Zhang, and G. C. Zhang (2009), Measurement of interstation phase velocity by wavelet transformation, Earth Sci., 22, 425-429, doi:10.1007/s11589-009-0425-3.
Xu, P., and D. Zhao (2009), Upper-mantle velocity structure beneath the North China Craton: Implications for lithospheric thinning, Geophys. J. Int., 177, 1279-1283, doi:10.1111/j.1365-246X.2009.04120.x.

Yanovskaya, T. B., and P. G. Ditmar (1990), Smoothness criteria in surface wave tomography, Geophys. J. Int., 102, 63-72.

Zhang, P. Z., Z. Shen, M. Wang, W. J. Gan, R. Burgmann, and P. Molnar (2004), Continuous deformation of the Tibetan Plateau from global positioning system data, Geology, 32, 809-812, doi:10.1130/G20554.1.

Zhao, L., R. M. Allen, T. Zheng, and S.-H. Hung (2009), Reactivation of an Archean craton: Constraints from $\mathrm{P}$ and $\mathrm{S}$ wave tomography in North China, Geophys. Res. Lett., 36, L17306, doi:10.1029/2009GL039781.

Zheng, S., X. Sun, X. Song, Y. Yang, and M. H. Ritzwoller (2008), Surface wave tomography of China from ambient seismic noise correlation, Geochem. Geophys. Geosyst., 9, Q05020, doi:10.1029/2008GC001981.

Zhou, X. M., and W. X. Li (2000), Origin of late Mesozoic igneous rocks in southeastern China: Implications for lithosphere subduction and underplating of mafic magmas, Tectonophysics, 326, 269-287, doi:10.1016/ S0040-1951(00)00120-7.

Zhou, Y., F. A. Dahlen, and G. Nolet (2004), Three-dimensional sensitivity kernels for surface wave observables, Geophys. J. Int., 158, 142-168, doi:10.1111/j.1365-246X.2004.02324.x.

Zhou, Y., F. A. Dahlen, G. Nolet, and G. Laske (2005), Finite-frequency effects in global surface-wave tomography, Geophys. J. Int., 163 1087-1111, doi:10.1111/j.1365-246X.2005.02780.x.

R. M. Allen, Seismological Laboratory, University of California, 215 McCone Hall, No. 4760, Berkeley, CA 94720-4760, USA. (rallen@berkeley. edu)

S.-H. Hung, Department of Geosciences, National Taiwan University, Taipei 10617, Taiwan. (shung@ntu.edu.tw)

M. Obrebski, Laboratoire d'Océanographie Spatiale, Centre Ifremer de Brest, Service DYNECO/PHYSED, Z.I pte du Diable, F-29280 Plouzané, France, (mathiasobrebski@yahoo.fr)

J. Pan, Q. Wu, and F. Zhang, Institute of Geophysics, Chinese Earthquake Administration, 5 Minzu Xueyuan South Rd., Haidian District, Beijing 100081, China. (panj151@gmail.com; wuqj@cea-igp. ac.cn; zhangfengxue336@163.com) 